\title{
Impact of Directors' Networks on Corporate Social Responsibility: A Cross Country Study
}

\begin{abstract}
We investigate the impact of directors' networks on corporate social responsibility (CSR) activities by using an unbalanced panel data of 2,023 publicly listed firms from 17 countries during 2003 - 2018. Drawing on network theory, stakeholder theory, and institutional theory, we find that directors' networks is positively related to their decision of CSR activities. Additionally, we find a positive relation between directors' networks and CSR during financial crises. Our results still hold after a set of sensitivity tests. The findings in our study expand the academic literature related to directors' networks and CSR activities, and assist policymakers and investors in understanding the importance of directors' networks as determining factor of CSR policies.
\end{abstract}

Keywords: Corporate Social Responsibility (CSR); Directors' Networks; Centrality; Financial Crisis; Governance; Cross country 


\section{Introduction}

To the best of our knowledge, this is the first cross-country study to exclusively examine the relationship between directors' networks and corporate social responsibility $\left(\mathrm{CSR}^{1}\right)$ activities. CSR activities have been considered as one of the worldwide corporate norms of successful businesses since the 1960s (Walls et al., 2012). Analysing a large sample of US listed firms, Ioannou and Serafeim (2012) show that during the past few decades, firms have substantially increased their investment for CSR activities for the welfare of their stakeholders. Deng et al. (2013) also find that most of the US firms have considered stakeholders in their value maximization models and have placed importance on CSR activities equal to profit and value enhancing activities. In a recent study to analyse time-varying investor's sentiment, Naughton et al. (2018) find that CSR activities can generate positive sentiment among investors. Konar and Cohen (2001) show that a poor environmental performance can negatively affect the intangible asset value of the firms.

The CSR-related decision is usually taken by Directors ${ }^{2}$ who are important stakeholders within firms. These directors monitor and improve the network of firms through their own connections (Francoeur et al., 2019; Larcker et al., 2013; Rossi et al., 2018). To maximize a firm's value, the directors consider various other stakeholders for their business operations and thus, to act in the interest of shareholders and stakeholders, they make strategic decisions with regards to a firm's CSR activities (Mason and Simmons 2014). Furthermore, directors' connections improve access to valuable information in terms of cost, quality, and timeliness (Singh and Delios, 2017).

Thus far, research has been separately conducted on the positive impact of directors' network and CSR activities on firm performance (Chahine et al., 2019). There is no evidence in literature about the direct relationship ${ }^{3}$ of director's network and firm's CSR activities in a cross-country setup. Therefore, in this paper we examine if there is any impact of directors' networks on firms' CSR activities. Since both CSR activities and directors' networks can generate higher value for firms, this study draws an intense attention of research scholars and adds to the following arguments. First, firms' CSR activities are associated with firms' longterm responsibility for the wider stakeholder community, i.e. the environment and society, leading to better performance of firms and welfare of stakeholders (Bhandari and Javakhadze,

\footnotetext{
${ }^{1}$ Following Del Bosco and Misani (2016), the proxies for CSR activities in this paper are the environment and social score. We collect the environment and social score from the Asset4 ESG database. The database is widely used in CSR related academic literature and its score ranging from 0 to100 representing the outcome of CSR activities of the firm on environment and social dimension. It allows the researcher to identify a firm's involvement in each dimension in details. From the definition of environment and social score measures by Thomson Reuters (2019), it is evident that the scores from Asset4 are suitable proxies for CSR activities that can capture the value generated by the environment and social activities of firms. See Appendix A for the definitions of the environmental and social pillars by Thomson Reuters (2019).

${ }^{2}$ Following Intintoli et al., (2018) and Rennebog and Zhao (2014), in the present study, we refer to Chief Executive Officers (CEOs), Chief Operating Officers (COOs), Chief Finance Officers (CFOs), executive and non-executive directors, and any other board member as a Director.

${ }^{3}$ In this paper we are using relationship and impact interchangeably.
} 
2017). Second, although CSR activities are costly, directors' networks are able to reduce the cost associated with the time required for information processing, which help directors to enhance profit of the firm and also allow directors to engage in expensive CSR activities to generate a socially responsible environment (Chahine et al., 2019).

By using an unbalanced panel of 2,023 publicly listed firms from 17 countries during 2003-2018, we find a positive and statistically significant relationship between directors' networks and CSR activities, which is consistent and economically significant during the financial crisis ${ }^{4}$ period. We measure director's connection and network as their centrality ${ }^{5}$ to examine the proposed research question. Centrality is a positional network which provides a clear understanding of directors' strategic networking positions (El-Khatib et al., 2015). Our detailed analysis of directors' networks can assist firms to achieve their "Corporate Strategy 2020." Moreover, the results may guide directors from developed and developing countries in identifying why it is necessary to strengthen their connections and how their networks can assist to successfully implement CSR activities within their firms during financial crisis. The findings from this work also be useful for policy- and decision-makers in guiding the firms in a value increasing CSR activity.

Our empirical model is supported by a comprehensive theoretical model based on the network theory, stakeholder theory and institutional theory. During the sample years, the firms voluntarily disclose ${ }^{6}$ detailed CSR activities to show their commitment towards society. Directors of a firm follow other directors in the same institutional framework, and by exchanging valuable cost-effective information within their connections, directors show high commitment of the firm towards the betterment of the stakeholders, e.g., environment and society. By using their connections in an institutional framework, to conduct CSR activities, directors build 'moral capital', , which leads to fewer penalties for any wrongdoing (Janney and Gove 2011). Our understanding of the relationship between directors' networks and CSR activities is an extension to the existing theories explaining the relationships between CSR, directors' networks and firm performance (Braun et al., 2018; Liu and Wu, 2016).

The theoretical and the empirical models of the present study contribute to the academic literature in several ways. First, our study extends the growing literature that argues that nonfinancial CSR information influences strategic decision making, which helps the firm to develop an advanced internal management control system (Casey and Grenier 2015). Second, by examining the formal and informal connections of directors and directors' position within the networks, we identify the importance of flow of financial and non-financial information among the directors. Thus, by introducing directors' networks in CSR literature, we extend

\footnotetext{
${ }^{4}$ We follow Cull and Peria (2013) to define crisis period in this study.

${ }^{5}$ Detail of the Centrality measures are explained in Appendix B

${ }^{6}$ Recently, some countries made it mandatory for firms to disclose certain information on CSR. For instance. since 2017, following the EU law (Directive 2014/95/EU) all firms from European member countries are required to produce a mandatory CSR report including certain information. For more details on types of information required, refer to Goloshchapova et al., 2019, Note no 3.

${ }^{7}$ Following Janney and Gove, (2011), we define 'moral capital' as "the resources that sustain a moral community". The core of moral capital consists of six fundamental relations: trust, loyalty, reciprocity, solidarity, respect and justice.
} 
the studies, where voluntary CSR activities related to disclosure assist firms in better costeffective operating decisions making by reducing the cost of external monitoring (Christensen 2016; Goh et al., 2018). Third, existing literature emphasises on a multi-country setting to understand a firm's social performance (see Cai et al., 2016). Most of the CSRbased studies are either country-specific (Boubakri et al., 2016) or related to firm's performance in a certain institutional framework (El Ghoul et al., 2017). So, by considering directors' networks across countries and its relationship to their CSR activities, we contribute to the cross-country studies in corporate finance.

The remainder of this paper is structured as follows: In Section 2, we review the relevant literature and develop two testable hypotheses explaining the relation between directors' networks and CSR activities; in Section 3, we present the research methodology; in Section 4 we discuss the main findings and analyse the endogeneity test; finally, in Section 5, we conclude the study and indicate the limitations and scope for further research.

\section{Literature Review and Hypotheses Development}

Centrality is a common way to measure directors' links in their connections in the network literature (Burt 1997). The network measures provide an understanding of directors' ability to obtain information, how powerful a director is in commanding others, and how directors can influence economic decision-making of the firm (El-Khatib et al., 2015). However, how the network can influence directors in the network to take similar decisions is yet to be examined. Market leaders can generate higher value for their own firm when they focus more on CSR compared to peers. So, there is a high possibility of herding behaviour among directors when they take CSR related decisions. The CSR decisions taken by directors motivate us to examine if the director's position in their network can influence other directors to engage in CSR activities.

Prior studies show that directors with strong networks - those who are wellconnected - possess many advantages in their connections, relative to directors with weak networks - those who are less connected (see Bonacich, 1972; Egginton and McCumber, 2019; El-Khatib et al., 2015; Faleye et al., 2014; Freeman 1977; Miranda-Lopez et al., 2018). The concept of well-connectedness involves many dimensions. Firstly, a director may be well-connected if he or she possesses many channels of resource exchange, giving him or her opportunities to share and receive relevant information faster than other directors (measured by Degree centrality). Secondly, a director may be well-connected if he or she possesses closer ties to other directors, i.e. there are fewer steps between other directors, making resource exchange quicker (measured by Closeness centrality). Thirdly, a director may be well-connected if he or she is on more paths between pairs of other directors, making themselves a key broker of resource exchange (measured by Betweenness centrality). Lastly, Eigenvector centrality measures consider the extent to which a director is connected with other highly connected directors. In the literature, it is evident that there exists a steady flow 
of information in directors network which in mostly a cost effective tool used by directors (Larcker et al., 2013).

The above-mentioned centrality measures can influence director's decision-making power, and they generate value from the collected information in their network (Horton et al., 2012). Following the network theory, we observe that the directors, at certain positions within a network, have greater access to valuable information that is relevant to a firm's strategic decision making such as, CSR activities and can also influence other directors in the network to take similar decisions (Larcker et al., 2013). By using the power and authority associated with their position in the networks, directors can assess a cost -benefit aspect associated with firm's growth. However, since directors have influence on credit availability (Khwaja and Mian 2005), they can exercise expensive and risky CSR activities by applying their knowledge gained through their own network. Directors get the opportunity to take advantage of discussion with other directors in the network with high experience in CSR in any critical situation, which allow them to develop growth-related strategy of the firm during financial crisis. By considering all stakeholders in a business model, directors can get better understanding about the demand of stakeholders of the business and accordingly can set the tone of the business including CSR focused activities. In a similar argument, Chung and Zhang (2011) show that the structure and quality of country-level governance can also influence the institutional setup for firms operating in a particular country. In other words, in a single country, the variation of corporate governance can generate an agency problem, which can show a higher investment by directors in CSR for their personal benefits instead of wider advantages. However, it is not conclusive that how the adverse impact of these firmand/or country-level variations on CSR decision can be minimised, when directors possess a position within the network. Thus, it is important to examine the influence of network among directors on their CSR activities in different institutional setup. Based on the abovementioned arguments, we formulate the following hypothesis:

\section{Hypothesis 1: Director's network is positively related to CSR activities}

The global financial crisis has led to a worldwide rethinking of the architecture of firms' financial systems. So, achieving a financial stability and developing a well-functioning market become the most essential strategy for firms after the financial crisis (Lins et al., 2017). Extant studies examine the relationship between firms' socially responsible behaviour and their financial performance during the financial crisis. For example, a recent stream of literature contends that firms pursue profit-maximizing CSR (e.g., Bénabou and Tirole, 2010, Garcia-Castro et al., 2010, Servaes and Tamayo, 2013) and get reward for their commitment to CSR in the form of higher values, lower cost of capital, and greater capital inflows (e.g., El Ghoul et al., 2011, Goss and Roberts, 2011, Jo and Harjoto, 2011) during the crisis. Thus, these studies are mostly in line with Margolis et al. (2009) which conduct a meta-analysis of 251 studies and conclude a positive relationship between corporate social performance and financial performance. The corporate social performance neither imposes financial penalties to firms nor impairs their economic functioning. But if a firm is performing badly then there 
is a pronounced adverse effect on the firm's financial performance. Thus, we can expect that, firms prefer to generate benefits by participating in CSR activities in any economic situation.

CSR is an expensive activity, and it can be more costly during the financial crisis as a lack of proper information can create a high risk in the market. Prior studies provide evidence regarding the relationship between firm's environmental and social behaviour and its financial performance during the financial crisis (e.g. Cornett et al., 2016). However, how can the access to networks, a form of social capital recourses, reduce a negative impact of stressful events, such as financial crisis? Directors often take support from their connections when they want to deal with economic hardship (Heemskerk 2013). Based on previous literature as discussed above, it is evident that interpersonal links are likely to affect director's CSR decision before and during the financial distress. Although, Cornett et al., (2016) documents that CSR activities are limited during the financial crisis, but these studies lack empirical evidence for different types of directors' networks and their impact on CSR activities before and during the financial crisis, which are influenced by the need of stakeholders of the firm. Since our cross-country sample spreads over the global financial crisis, thus, it is important to investigate whether the directors' networks remain important in determining CSR during the financial crisis as in normal economic situations in various institutional frameworks.

Although CSR activities become increasingly important, Chen and Bouvain (2009) show that CSR activities vary significantly from country to country during the financial crisis. Brito (2001) develops an institutional approach to analyse collective actions in industrial networks and institutional relationships that can support directors' decision-making process in certain industries. Institutional differences can also influence the directors' intentions to develop connections. However, being in a network, directors can improve their financial and non-financial decision making when they get information from their peers (Omer et al., 2018). During the financial crisis, directors in a network can avoid misstating annual reports because of their access to critical market wide information. Such information can allow the directors to deal with the financial crisis without sacrificing their personal benefit. The network-based informational advantage can allow the directors to take value generating CSR activities during the crisis. Thus, it is important to examine whether the impact of directors' networks on CSR decision remains same during the financial crisis at different institutional setup. So, our second hypothesis is:

Hypothesis 2: The impact of director's networks on CSR activities increases during financial crisis

\section{Methods}

\subsection{Sample}

We begin with board-related data from the BoardEx database for the sample period of 20032018. We include only those firms where information of directors, and their linked directors' 
identifications are available. As a result of excluding all financial ${ }^{8}$ firms, we have 3,492 firms. We merge these non-financial firms with environmental and social scores from the Thomson Reuter's ASSET4 ESG database and financial data from Worldscope using International Securities Identification Number (ISIN) code. ASSET4 is an established source for environmental, social and governance (hereafter referred to as ESG) information used by researchers to measure CSR (Cheng et al., 2014) ${ }^{9}$. Our final sample consists of an unbalanced panel of 19,721 firm-year observations, covering relevant information on 57,266 unique directors from 2,023 firms in 17 countries during the period from 2003 to 2018.

\subsection{Variable Description ${ }^{10}$}

Following El-Khatib et al. (2015), we use degree, closeness, betweenness, and eigenvector to calculate centrality to evaluate the position of a director within a network. Degree measures all the direct links that each director has with other directors in the networks. The degree centrality takes the most information in an account to which a director is visible because it measures the fraction of directors to which the director is connected. Closeness measures the number of steps that a director needs to take within their networks to reach another director. This variable captures the connection to highly influential directors. Betweenness measures the shortest paths linking two directors in the connections. Betweenness captures the absolute position of a director in the networks. Finally, eigenvector network extends the degree centrality and measures the connections by weighing degree networks based on the importance of direct connections of a director. Eigenvector networks can be interpreted as capturing notions of power and prestige, giving it a special advantage in obtaining resources and valuable information. In our main analysis, we construct yearly connections based on director's employment history. To make our networks measures comparable across time, we follow El-Khatib et al., (2015) and Omer et al., (2019) and construct the percentile values of the networks measures annually, with 1 being the least central and 100 being the most central. These percentiles measure the position of the directors within the networks of all listed firms in the entire Boardex database. This rank order of the connections explains the importance of each director and permit a clear and simple interpretation of the variables.

Following Cheng et al., (2014) and Del Bosco and Misani (2016), we calculate the following proxies for CSR from the environment and social scores of our sample firms.

\footnotetext{
${ }^{8}$ Following the literature, we exclude the financial firms from the sample. The reporting practice is different in financial firms so in previous research these firms are not included in the sample. Because of the differences in accounting practices and reporting style of financial firms, the inclusion or exclusion of them will not bias the findings associated with non-financial firms (Boubaker et al., 2014).

${ }^{9}$ ASSET4 collected data and scores for firms on ESG dimensions since the 2002 fiscal year. ASSET4 database has a team of 125 analysts who collected information on over 900 evaluation points per firm. According to their guidelines, the primary data used must be objective and publicly available. Subsequently, these data points were combined into 226 key performance indicators (KPIs), which make up the basis of the rating process of a firm's three performance pillars: environmental, social and governance. ASSET4 then transformed this information into ratings through a system that assigns weights to each KPI following several industry considerations. To form a firm's rating pillar, ASSET4 added up the products of each KPI and its weight for each pillar.

${ }^{10}$ For variable definitions, see Appendix A
} 
Environment Score (ES): We calculate ES using the environment pillar of ASSET4 database. These dimensions show how a firm uses their practices to generate long-term shareholder value by measuring the impact on natural systems. ES is based on three categories: resource reduction, emission reduction, and product innovation. ASSET4 assigns a value from 0 to 100, with higher values indicating better ES. Social Score (SS): The second pillar indicates a firm's capacity to generate trust and loyalty with its workforce, customers, and society through its use of best management practices and the firm's reputation (Cheng et al., 2014). We measure SS using the ASSET4's social pillar. SS is based on seven categories including employment quality, health and safety issues, training, diversity, human rights, community involvement, and product responsibility. The variable takes the values from 0 to 100 , with higher values indicating higher SS levels. We consider the environmental and social score separately to get a detail understanding about firm's ESG (see Lys et al., 2015). These scores are adjusted for skewness and fitted to a curve to create ratings between 0 and 100 .

\section{Firm-specific and country control variables}

We include several firm-specific control variables in our estimations that can affect the relationship between directors' networks and CSR activities. We control for Firm Size calculated as a natural logarithm of total assets (Cheng et al., 2014), ROE -measured as Net income divided by book value on equity (Walls et al., 2012), Leverage ${ }^{11}$-measured as ratio of debt-to-common equity using Worldscope data item WC08231, Liquidity $^{12}$ calculated as net sales divided by the net receivable (Krueger, 2015). Following Singh and Delios (2017), we use Board size as the total number of directors on the board, and Duality calculated as a binary variable that takes 1 when a CEO or member of the executive board also the chairman of the board, and 0 otherwise. We include GDP per capita and Inflation to control for country level variations (Ferris et al., 2017). Following Cull and Peria (2013), we construct a dummy variable for the financial crisis covering period 2007 - 2008. We also control for Hofstede's $(1984 ; 2001 ; 2010)$ six dimensions of cultures such as: power distance (PDI), individualism (INDI), masculinity (MAS), uncertainty avoidance (UAI), long-term orientation (LTO), indulgence versus restraint (IVR) (for detail explanation of each dimension please see Hofstede 2010). Cultural differences at country level can affect director's decision making and also their interests in networking.

An impressive set of studies considers alternative measures of corporate governance and shows the impact of these governance measures on firm performance (Bhagat and Bolton, 2008). We examine firm-level governance measures constructed by using data from ASSET4. Because of the existence of agency problem, managers may prefer to invest in CSR to fulfil their personal benefits. Thus, there is a possibility of observing a positive and statistically significant relationships between directors' networks and investment in CSR

\footnotetext{
${ }^{11}$ See Balafas et al. (2018)

${ }^{12}$ See Kruger (2015)
} 
(Krueger, 2015), even in a firm with weaker corporate governance. To test how strong or weak corporate governance can influence the relationship between director network and CSR, we include G-index (ranging from 0 to 24) in our empirical model. The higher value of Gindex indicates weaker shareholder rights (see Gompers et al., 2003). These provisions are calculated as one point for each of the following charter provisions that a firm has- such as staggered board, a supermajority, golden parachute, by-laws, mergers and the existence of poison pills (Bebchuk et al., 2011).

\section{[Insert Table 1 about here]}

\subsection{Descriptive Statistics}

Panel A of Table 1 presents the descriptive statistics for the above-mentioned variables. The table shows the mean values of $E S$ and $S S$ are 53.86 and 56.80 respectively. The mean (and standard deviation) of degree, closeness, betweenness, and eigenvector centrality are 0.514 (0.283), 0.48 (0.289), 833.59 (512.2) and 0.513 (0.282) respectively. These statistics are consistent with Faleye et al., (2014). However, their study is only for the USA and thus, we have lower mean values for ES and SS. The above-mentioned centrality measures are based on directors in a particular financial year. Overall, the descriptive statistics of director networks measures are in line with recent studies (e.g. Miranda-Lopez et al., 2018). The mean value of the Firm Size is 8.63 which indicates that most of the sample firms are big firms and that can be a reason of higher $R O E$. The control variables show that the sample firms demonstrate normal operating performance. The mean of the governance variables, e.g. the Duality is 0.195 which are consistent with literature (Balsam et al., 2017 and Finkelstein and Daveni 1994). All continuous variables are winsorised at the $1^{\text {st }}$ and $99^{\text {th }}$ percentiles.

The Panel B Table 1 reports the mean values of ES and SS by country. The table shows that Indonesia, Thailand, Japan and South Africa are higher in environment scores as well as social scores, while countries such as Australia, Israel and Egypt have low ES and SS. In terms of firm-year observation, USA, UK, Australia, and Japan are the bigger countries, while Egypt, New Zealand have noticeably had lower number of firms covered in our sample. In robustness tests, we estimate our empirical models after removing USA, UK, Australia and Japan and estimators qualitatively remain unchanged. The table also presents the industry distribution by country (based on 2-digit SIC code). The impact of social pressure created by public is different from one industry to other (Harjoto et al., 2015), thus we control for industry in the empirical models. Altogether, we have 2,023 firms spreading over 17 industries.

[Insert Table 2 about here]

Table 2 presents the Pearson (below the diagonal) and Spearman (above the diagonal) correlation coefficients for all the variables used in the main analysis. Not surprisingly, the correlation coefficients between director's networks and CSR are positive and significant. We use variance inflation factor (VIF) to assess the collinearity of the variables used in the 
models. We find the VIF values of our variables are below the indicative threshold value of 10 (see Hair et al., 2010). Appendix C reports the VIF values.

\section{Results and Discussion}

\subsection{Identification strategy}

In this section, we find global evidence about how director's position in their networks affect their firms' CSR. We prefer Ordinary Least Square (OLS) as our primary regression for analysis. However, the firm specific and industry specific unobserved heterogeneity (as CSR defers industry to industry) is randomly correlated with error terms. Thus, we include timeinvariant variable- such as industry dummies in our model. The Breusch and Pagan Lagrangian multiplier test rejects the null hypothesis of absence of unobserved heterogeneity.

The baseline model of our paper is given below:

$$
\begin{aligned}
Y_{i t}=\beta_{0}+\beta_{1} X_{i t} & +\beta_{2} \text { ROE }_{i t}+\beta_{3} \text { Firm }_{\text {Size }}+\beta_{4} \text { Leverage }_{i t}+\beta_{5} \text { Liquidity }_{i t}+\beta_{6} \text { Duality }_{i t} \\
& +\beta_{7} \text { Index }_{i t}+\beta_{8} \text { PDI }_{i t}+\beta_{9} \text { INDI }_{i t}+\beta_{10} M A S_{i t}+\beta_{11} \text { UAI }_{i t}+\beta_{12} \text { LTO }_{i t}+\beta_{13} I_{\text {IVR }} \\
& +\beta_{14} \text { G_Index }_{i t}+\beta_{15} \text { Inflation }_{j t}+\beta_{16} \text { GDP }_{j t}+\beta_{17} \text { Industry dummies }+v_{i t} \ldots \ldots . . .(1)
\end{aligned}
$$

Where, $Y_{i t}$ is the Environmental and Social Scores (proxy for CSR $)^{13}, X_{i t}$ is the vector of four centrality measures - degree, closeness, betweenness, and eigenvector. The error terms $v_{i t}=$ $\alpha_{i}+\varepsilon_{i t}$, where $\alpha_{i}$ is the firm-specific unobserved heterogeneity, and $\varepsilon_{i t}$ is iid.

\section{[Insert Table 3 about here]}

\subsection{Empirical Analysis}

To find the empirical support for Hypothesis 1, we include four measures of centrality degree, betweenness, closeness and eigenvector in a stepwise manner i.e. each centrality measure at a time in our regression models. The Panels A and B of Table 3 represent the impact of centrality on environment score and social score respectively. To estimate the parameters of interest, we use several models. In Models 1, 4, 7 and 10 (Panel A), we report OLS regression results, where heteroskedasticity-robust standard errors are clustered at the firm level. The coefficients of degree, closeness, betweenness and eigenvector centrality are $\left(\beta_{1}=44.876, \mathrm{p}<0.01\right),\left(\beta_{1}=48.654, \mathrm{p}<0.01\right),\left(\beta_{1}=0.024, \mathrm{p}<0.01\right)$, and $\left(\beta_{1}=45.669, \mathrm{p}<\right.$ $0.01)$ respectively, which are positive and statistically significant. High degree centrality means, directors at the firm level are active and connected with directors of their own or other

\footnotetext{
${ }^{13}$ Following Dyck et al., (2019), we also use logs of ES and SS (not reported) to reduce the effect of outliers. But our main results remain unaffected.
} 
firms. The coefficients indicate that the more connections possessed by directors in a network, the more the engagement by firms in CSR activities. So, there is a possibility that the directors divert their valuable time and effort in multiple responsibilities, and they obtain valuable information at a less cost through their networks. In addition, we observe that the directors' networks increase the social performance more than the environment performance. Economically, for instance, we observe that on average, the degree, closeness, betweenness and eigenvector centralities increase the social performance 3.75\% (Model 1- Panel B- SS: 46.5605 and Model 1- Panel A -ES: 44.8765), 12.81\% (Model 4- Panel B- SS: 54.8888 and Model 4- Panel A -ES: 48.6541), 0.83\% (Model 7- Panel B- SS: 0.0246 and Model 7- Panel A -ES: 0.0242) and 3.66\% (Model 10- Panel B- SS: 47.3420 and Model 10- Panel A -ES: 45.6698) respectively more that the environmental performance. Following Boubaker et al. (2019), in models 2-3, 5-6, 8-9 and 11-12 of Panel A, we use the Prais-Winsten and NeweyWest procedures to account for serial correlation in the error terms. In both the Panels A and $\mathrm{B}$, across all the models, we find that the coefficients of centrality are positive and statistically significant at the $1 \%$ level, suggesting that the director's networks positively impact CSR activities of firms. The results offer supports to our Hypothesis 1, which predicts that a positive relationship between the director's networks and CSR.

Our second hypothesis predicts that the impact of director's networks on CSR activities increases during the financial crisis. We use a difference-in-differences (DiD) estimation to examine our Hypothesis 2. Following Renneboog and Zhao (2011), we categorise two types of centrality - direct and indirect centralities. While, direct centrality is measured by degree and eigenvector centralities, the indirect centrality is measured by the closeness and betweenness centralities. Both Granovetter (1973) and Renneboog and Zhao (2011) suggest that indirect centrality measures are better proxies for the stronger network connections than the direct centrality. The reason is, directly connected individuals possess redundant (similar) information sources. So, in terms of novel and unique information collection efficiency, betweenness and closeness centrality measures are better indicators of directors' ties, compared to the eigenvector and degree centralities. Following the abovementioned arguments, we create a dummy variable - called strong connections (strong conn) equal to 1 when the closeness and betweenness centralities values are above the median values of these two variables and 0 otherwise. The group consists of directors with strong connections is a treatment group and the group below the median values is the control group for our DiD analysis.

On the one side, we include a dummy variable that distinguishes the crisis period from the non-crisis and post crisis periods. On the other, we include either firms with strong and efficient network connections (treatment) and weak network connections (control) groups. We then use an interaction terms between the crisis and treatment dummies to test the impact of treatment on the increase of CSR activities in financial crisis period.

Our baseline panel specification is as follows:

$$
\begin{gathered}
\text { CSR }_{i j t}=\beta_{0}+ \\
\beta_{1} \text { Strong_Conn }_{i j t}+\beta_{2} \text { Crisis }_{t}+\beta_{3} \text { Strong_Conn }_{i j t} * \text { Crisis }_{t}+\beta_{4} X_{i j t} \\
+\beta_{4} \text { Culture }_{j t}+\text { Industry effects }+ \text { Year effects }+\epsilon_{i t} \ldots(2)
\end{gathered}
$$


Where, $\operatorname{CSR}_{i t}$ is the CSR activities of firms $\mathrm{i}$ in country $\mathrm{j}$ and in year $\mathrm{t} ; \beta_{0}$ is the intercept; $\beta_{n}$ is the vector of coefficients; Strong_Conn $n_{i j t}$ is a dummy variable equal to 1 if the closeness and betweenness centralities values are above the median of these variables and 0 otherwise. Crisis is a dummy variable indicating financial crisis. We include this variable in several ways- (1) following De Hass et al. (2015) we define each year from 2008 to 2011 as financial crisis year, (2) following Cull and Peria (2013) we define crisis period as a dummy variable equals to 1 for the year 2007-2008 and 0 otherwise. We also include a variable called Post-Crisis equal to 1 when the year is 2009 and onwards, and 0 otherwise. $X_{i j t}$ is the firm specific control variables, Culture $_{j t}$ is a vector of national culture variables of countries $\mathrm{j}$ in year $\mathrm{t}$ indicating power distance, individualism, masculinity, uncertainty avoidance, long-term orientation and indulgence versus restraint. We control for industry and year heterogeneity by including the dummies for these variables. $\epsilon_{i t}$ is the error terms.

[Insert Table 4 about here]

The Columns 1- 2 of Table 4 show the results of our DiD estimation. The results show that the coefficient of interaction terms of Year 2010 and 2011 with the Strong Conn are positive and statistically significant as expected. However, the coefficients for the interaction terms of Year 2008 and 2009 are either negative or not significant. We believe that this is because during the early stage of the financial crisis, directors and firms have started re-organising themselves to cope with the sudden change in the financial and international markets. So, the effect of networks is opposite to our expectations. Columns 3-4 of the Table 4 show positive and statistically significant coefficients as we expect. This informs us that dynamics of networking are gained due to the financial crisis and its effect on CSR activities continues in the post financial crisis periods.

The validity of our DiD estimation depends on the parallel-trend assumptions. In other words, DiD analysis assumes that the CSR activities show a parallel trend between treated and control groups in pre-crisis period. To mitigate this issue, following Bertrand and Mullainathan (2003) we create 4 dummy variables After ${ }^{1}$, After ${ }^{2+}$ (equal to one for those firms that will be affected by financial crisis in two or more years, 0 otherwise) and Before ${ }^{1}$, Before $^{2+}$ (equal to 1 for those firms that are affected by financial crisis one year ago or 2 or more than 2 years ago). In Column 5-6 of the Table 4, we find that while coefficient of Before $^{1}$ and Before ${ }^{2+}$ are not statistically significant, the coefficients of After ${ }^{1}$ and After ${ }^{2+}$ are positive and significant, suggesting that increase of CSR activities continues after the financial crisis. So, the results help us to conclude that the effect of director's networks on CSR activities is unlikely to be driven by reverse causality. In addition to these tests, we also created a new variable (Placebo) by randomly assigning falsified financial crisis periods to the sample firms. Our intention is if the placebo dummy shows a statistically significant coefficient, we conclude that our results for DiD related to the role of financial crisis is doubtful. The Column 7-8 displays non-significant coefficients which confirm the validity of 
our results. Overall, our quasi-natural experiment establishes the robustness of our conclusion related to the Hypothesis 2.

\subsubsection{Addressing endogeneity}

In our hypotheses, we predict the causal explanations in Equation 1 for $\beta_{1}>0$ for director's networks, wherein director's positional advantage in a connection can influence the level of CSR of their firms. However, the results in support of our hypotheses shown in Table 4 can be weaker in the absence of persuasive instruments and proper estimation addressing a potential endogeneity issue. In the following section, we address this with several specifications.

\subsubsection{Addressing the reverse causality}

[Insert Table 5 about here]

The statistical inference in prior studies related to director's networks, may be erroneous if the results are attributable to reverse causality. Directors may develop a bigger connection quickly compared to others when they become successful with similar activities in their earlier employment (Fracassi and Tate, 2012). There is a possibility that the directors would remain successful in CSR activities in their past firms and thus, we may observe a positive relationship between CSR and any director's networks variable. Evidence from extant studies shows regressing the dependent variable on lagged or lead values of independent variable (or vice versa) can mitigate the problem of reverse causality (Cheng 2008; Faleye et al., 2014). The assumption behind using lagged value is that the historical success story of the directors is predetermined. Moreover, the assumption behind the lead dependent variable is that the director's networks can reduce the ex-post risk associated with CSR activities. To address the reverse causality problem, we use two-year lead value of the dependent variable (ES and SS). The implemented approach allows us to control for any impact of previous connections of the directors and also if better CSR activities influence directors to expand their connections from the present level. The approach followed in this study gives us enough scope for the covariates to explain the dependent variable without losing the variation in the data by using lagged value of the dependent variables. In Table 5, we find positive and statistically significant coefficients for all the four director's networks measures. The results reported in Table 5 suggest that the findings in the main results (reported in Table 3 ) are not due to reverse causality issue.

[Insert Table 6 about here]

\subsubsection{Instrumental variable regression}


To address the potential endogeneity arising from omitted unobserved heterogeneity, we follow Faleye et al., (2014) and select two instrumental variables - (a) UGrad: a binary variable equals to 1 if directors earned a graduate degree in any field, and 0 otherwise, and (b) Board size: number of total directors on a board in which directors have worked in the past. The above-mentioned instrumental variables are related to the director's network measures but not related to the firm's CSR activities. The graduate degree creates provision for the director to develop network. In the same way, when directors are part of a large sized board, the director can develop connections with other directors with whom they worked in the past. While working together in the past as board members assists director to generate benefit from networking. However, primarily the directors do not join a larger board to increase the CSR of their own firms.

We use the first-stage R-squared (reported in both in Panel A and B of Table 6), Kleibergen-Paap rk Wald F-statistic for weak instrument test and Hansen J-statistics for overidentification test for the validity of chosen instruments. To estimate Equation 1, we use two-stage least square (2SLS) regression. In the first stage, we include all the control variables and regress the instruments on the director's networks measures. In the second stage of the 2SLS estimation, we include the fitted value of each network measure in Equation 1. We find that the coefficients of director's networks are positive and statistically significant. The results are reported in Panel A and B.

\subsection{Robustness tests}

\subsubsection{Self-selection bias}

[Insert Table 7 about here]

Knyazeva et al. (2013) suggest that highly skilled and popular directors have high demand to join larger firms for greater reputational benefits. Moreover, it has been documented in several studies that larger firms may want to do more CSR activities (McElroy and Seigfried $1985)$ for their more visibility in society. On the other hand, directors in smaller firms may have less opportunity to develop bigger connections or join larger firms, although smaller firms may involve in CSR through donations. In the Panels A and B of Table 7, we revisite the OLS regression estimations on environment and social scores where we split large (top quartile based on firm size proxied by industry adjusted natural logarithm of total assets) and small firms (Intintoli et al., 2018). The results presented in Panel A and B, further confirm our previous findings.

\subsubsection{Unobserved heterogeneity}


To control for heteroskedasticity and no serial correlation, we also use random effects GLS estimation. A GLS regression is more suitable in this case as it corrects the omitted variable bias, and the presence of autocorrelation and heteroskedasticity in pooled cross-sectional data. Further we use a random-effect estimation over fixed-effect as some of the variables, such as country control variables, are time invariant. However, in order for random-effect estimation to be appropriate, the unobserved heterogeneity should not be correlated with the independent variables. We test this assumption and the suitability of random-effects estimation using Hausman test after removing the time invariant variables. The insignificant Hausman test statistics suggests that the assumptions for random effects estimation are not violated.

In Panels $\mathrm{C}$ and $\mathrm{D}$ of Table 7, we replace two control variables leverage and liquidity with different construction following Klasa et al. (2018) and Vithessonthi et al. (2017) respectively. The leverage is measured as book value of long-term debt plus debt in current liabilities minus short and long-term investments divided by total assets. The liquidity is calculated as the ratio of of current assets to current liabilities. Similar to Table 6, using 2SLS with UGrad and Board Size as instruments and control variables, we find that the relationship between director network and environment (and social) score remains unchanged.

\section{[Insert Table 8 about here]}

We test Equation 1 using random effects using control variables used in Table 3. The Panel A represents the results of random effects using the CSR as a dependent variable and director's networks as independent variables. We find positive and statistically significant coefficients that support our initial results in OLS regressions. In addition, in Panel B, we also use Heckman selection procedure. We again find that director's networks are positive and statistically significant with environment and social score for all the models (Columns 18).

\subsubsection{The role of corporate governance}

[Insert Table 9 about here]

We further perform a set of cross-sectional tests to examine whether the director's networks serve as a governance mechanism to affect the CSR activities. If the governance view holds, the director's networks may serve as either substitute or a compliment to other governance mechanisms. Therefore, we expect the effect of director's networks to vary with strength of traditional governance mechanisms. Following Cheng et al. (2019), we adopt G-index as a proxy for governance. To measure firms' low and high G-index, we split the sample firms by the median value of the governance variable. Table 9 represents the results, in which we find that the effect of director's networks on CSR is negative and significant for firms with low Gindex. On the other side, we find that the effect of director's networks on CSR is positive and statistically significant for firms with high G-index. The results suggest that the role of 
governance in networks is unlikely a driver of the director's networks and CSR for good governance firms (Bhandari and Javakhadze, 2017).

\subsubsection{Personal and Professional Networks}

Network theory states that the networks among directors allow information to be processed and diffused effectively either to create opportunities or hinder the growth of a firm. Although, a variation in directors' networks is observed across different centrality dimensions, the network is also an important predictor of firm performance (Chuluun et al., 2017). Following Intintoli et al. (2018), we define director's personal networks as total number of directors with whom the focal director attended the same institutions, graduated within two years and awarded similar type of academic degrees. We define the professional networks as the total number of directors with whom the focal director shares a common

board. Past or current professional connections can help directors to determine the quantity and quality of diverse information they can access through their networks (Engelberg et al., 2012). The personal and professional network help the directors to access to superior information and thus, these directors are in high demand within the market (Intintoli et al., 2018).

\section{[Insert Table 10 about here]}

Prior studies prove that firms with better professional connections among directors can earn higher returns (Larcker et al., 2013). However, information spillover in the professional network can also diffuse firm value, thereby decreasing management practices (Bizjak et al., 2009). Since directors implement CSR activities for long-term sustainability within the market, and to help protect their firms from future scandals, we assume that directors use their personal and professional networks to disseminate positive and costbeneficial information related to CSR activities. We find a positive and statistically significant impact of director's personal and professional networks, suggesting that director's previous and current connections influence CSR decision.

\subsubsection{Influence of Industry observation}

Many firms concentrate in the following industries in our sample: such as Constructions and Building materials (SIC 15), Electronic and Electrical Equipment (SIC 36), Mining (SIC 10) and Transport (SIC 47). To check if these industries influence the results, we removed theses industries and re-run the main estimations and found no significant differences (not reported).

\section{Conclusion}

In this paper, we examine the impact of the directors' networks on CSR activities across countries. During the last decades, the CSR infrastructure has made it increasingly imperative for firms to improve the effects of their business on people, the environment and society. Firms, which ignore stakeholders and prefer not to pay attention to CSR activities, find it both expensive and difficult to sustain in business (Ioannou and Serafeim, 2015). Considering 
stakeholders (e.g. investors, customers, environment, society, etc.) along with shareholders in carrying the business, firms signal their long-term responsibility towards the environment and society. Such positive indications in the market allow firms to be better off compared to their peers and motivate firms to invest more in financially viable CSR activities (Miranda-Lopez et al., 2018). By investing in CSR activities, firms can avoid severe punishment for not considering the sustainable approach in business (Jenney and Gove 2011).

The roles of directors within firms are very important as their ethical decisions generates more wealth in the firm, which have a huge impact on the director's pay package. The widely discussed constraints of investing in CSR activities are the costs associated with these activities (Ioannou and Serafeim, 2015). Usually, directors lack confidence or are not capable of incorporating CSR activities in the business model because of a lack of advanced information, which increases agency costs (Yuan et al., 2017).

By developing a comprehensive empirical robust model, we explain how director's networks can be used as a source of information in their risk-management strategy. Directors take risks when they invest more in CSR activities to generate higher values; however, the CSR can help earning a goodwill for the firms in the long run.

In terms of the contribution, this is the first study that thoroughly examines the relationship between CSR activities and types of directors' networks. To test this relationship, we use 2,023 firms across 17 countries between the period of 2003 to 2018 . By applying the network theory, stakeholder theory and institutional theory, we find a specific direction of causality, which is directors' networks influence the CSR activities. We also find that director's networks and CSR activities have a positive and statistically significant relationship. The economic significance of our findings remains unchanged in the robustness tests, including several specifications for addressing endogeneity and omitted variable bias.

According to the initiative "Corporate 2020", firms should redesign their relationships with stakeholders for a sustainable business model. Our findings suggest that directors' networks can assist firms in taking multidimensional CSR activities and strengthen a firm's relationship with shareholders and stakeholders at the same time. In addition, the findings state that during the financial crisis, the directors can share valuable information in a costbeneficial manner by applying their connections and continuing their CSR activities, which can put them at the forefront in the market. The findings are consistent with the literature on CSR, directors' networks, and financial crises (e.g. Faleye et al., 2014; Francoeur et al., 2019). The findings of the paper have substantially expanded the academic discussion on the inclusion of stakeholders within the business model and the cost-benefit information diffusion in directors' networks. By considering voluntary disclosure of CSR initiatives in different institutional frameworks, we establish the importance of doing similar research at a cross-country level. Our findings provide sufficient information to investors to assess the value of the firm and the policy makers can identify the importance of network in their decision making. 
This study is not without limitations. We use the ASSET4 environment and social scores as proxies for CSR activities. Text analysis of qualitative information related to CSR activities can generate more useful information about a firm's social and environmental responsibilities. Additional information on different types of mandatory CSR information can improve the findings. We use time variant firm-level instruments to capture reverse causality but additional instruments at the director level can strengthen the empirical model. We expect the results of this study to motivate additional research on the relationship between directors' networks and CSR activities, which can provide a more complete understanding of the effects of directors' connections and the impact of the same on CSR activities. 


\section{References}

Adams, R.B. and Ferreira, D. 2008. "Do directors perform for pay?". Journal of Accounting and Economics, 46 (1): 154-171.

Balsam, S., Kwack, S.Y. and Lee, J.Y. 2017. "Network connections, CEO compensation and involuntary turnover: The impact of a friend of a friend". Journal of Corporate Finance, 45: 220-244.

Balafas, N., Florackis, C., and Kostakis, A. 2018. "Monetary policy shocks and financially constrained shock returns: the effects of financial crisis." International Review of Financial Analysis, 58: 69-90

Bebchuk, L.A., Cremers, K.M. and Peyer, U.C. 2011. "The CEO pay slice". Journal of Financial Economics, 102(1): 199-221.

Benabou, R. and Tirole, J. 2010. "Individual and corporate social responsibility". Economica 77(305): 1-19.

Bhagat, S. and Bolton, B., 2008. "Corporate governance and firm performance". Journal of corporate finance, 14(3):257-273.

Bhandari, A. and Javakhadze, D., 2017. "Corporate social responsibility and capital allocation efficiency”. Journal of Corporate Finance, 43: 354-377.

Bizjak, J., Lemmon, M. and Whitby, R. 2009. "Product market competition and labor investment efficiency". FMA Conference.

Bonacich, P., 1972. "Factoring and weighting approaches to status scores and clique identification". Journal of mathematical sociology, 2(1): 113-120.

Boubakri, N., El Ghoul, S., Wang, H., Guedhami, O. and Kwok, C.C. 2016. "Cross-listing and corporate social responsibility". Journal of Corporate Finance, 41: 123-138.

Boubaker, S., Mansali, H., Rjiba., H. 2014. "Large controlling shareholders and stock price synchronicity”. Journal of Banking and Finance 40: 80-96.

Boubaker, S., Dang, V.A. and Sassi, S., 2019. "Investment efficiency and product market competition". Journal of Financial and Quantitative Analysis, 52(6): 2611-2642.

Braun, M., Briones, I. and Islas, G. 2018. "Interlocking directorates, access to credit, and business performance in Chile during early industrialization". Journal of Business Research. (In Press).

Brito, C.M. 2001. "Towards an institutional theory of the dynamics of industrial networks". Journal of Business and Industrial Marketing, 16 (3): 150-166.

Burt, Ronald S. 1997. "The Contingent Value of Social Capital". Administrative Science Quarterly 42 (2): 339-365. 
Casey, R.J. and Grenier, J.H. 2015. "Understanding and contributing to the enigma of corporate social responsibility (CSR) assurance in the United States". Auditing: A Journal of Practice \& Theory, 34(1): 97-130.

Chahine, S., Fang, Y., Hasan, I. and Mazboudi, M., 2019. "Entrenchment through corporate social responsibility: Evidence from CEO network centrality". International Review of Financial Analysis.

Chen, L., Srinidhi, B., Tsang, A. and Yu, W. 2016. "Audited financial reporting and voluntary disclosure of corporate social responsibility (CSR) reports". Journal of Management Accounting Research, 28 (2): 53-76.

Chen, S. and Bouvain, P. 2009. "Is corporate responsibility converging? A comparison of corporate responsibility reporting in the USA, UK, Australia, and Germany”. Journal of Business Ethics, 87 (1): 299-317.

Cheng, B., Ioannou, I. and Serafeim, G. 2014. "Corporate social responsibility and access to finance: CSR and access to finance”. Strategic Management Journal 35 (1): 1-23.

Cheng, S., Felix, R. and Zhao, Y., 2019. "Board interlock networks and informed short sales”. Journal of Banking \& Finance, 98:198-211.

Cheng, S. 2008. "Board size and the variability of corporate performance". Journal of Financial Economics, 87 (1): 157-176.

Chung, K. H., and H. Zhang, 2011, "Corporate Governance and Institutional Ownership". Journal of Financial Quantitative and Analysis, 46 (1): 247-273.

Christensen, D.M. 2016. "Corporate accountability reporting and high-profile misconduct". The Accounting Review, 91 (2): 377-399.

Chuluun, T., Andrew P., and A. Upadhyay. 2017. "Firm network structure and innovation". Journal of Corporate Finance 44: 193-214.

Cornett, M.M., Erhemjamts, O. and Tehranian, H. 2016. "Greed or good deeds: An examination of the relation between corporate social responsibility and the financial performance of US commercial banks around the financial crisis". Journal of Banking and Finance, 70: 37-159.

Cull, R. and Peria, M.S.M. 2013. "Bank ownership and lending patterns during the 20082009 financial crisis: Evidence from Latin America and Eastern Europe". Journal of Banking and Finance, 37 (12): 4861-4878.

Davis, G.F. 1991. “Agents without principles? The spread”. Administrative Science Quarterly, 36 (4): 583-613.

Del Bosco, B. and Misani, N. 2016. "The effect of cross-listing on the environmental, social, and governance performance of firms". Journal of World Business, 51 (6): 977-990. 
De Haas, R., Korniyenko, Y., and Pivovarsky, A. 2015. "Taming the herd? Foreign banks, the Vienna Initiative and crisis transmission". Journal of Financial Intermediation, 24: 325355

Deng, X., Kang, J.K. and Low, B.S. 2013. "Corporate social responsibility and stakeholder value maximization: Evidence from mergers". Journal of Financial Economics, 110 (1): 87109.

Dyck, A., Lins, K.V., Roth, L. and Wagner, H.F. 2019. "Do institutional investors drive corporate social responsibility? International evidence". Journal of Financial Economics, 131 (3): 693-714.

Egginton, J.F. and McCumber, W.R. 2019. "Executive Network Centrality and Stock Liquidity". Financial Management, 48(3): 849-871.

El Ghoul, S., Guedhami, O. and Kim, Y. 2017. "Country-level institutions, firm value, and the role of corporate social responsibility initiatives". Journal of International Business Studies, 48 (3): 360-385.

El-Khatib, R., Fogel, K. and Jandik, T. 2015. "CEO network centrality and merger performance”. Journal of Financial Economics, 116 (2): 349-382.

Engelberg, J., Gao, P. and Parsons, C.A. 2012. "Friends with money". Journal of Financial Economics, 103 (1): 169-188.

Fahlenbrach, R., Low, A. and Stulz, R.M. 2017. "Do independent director departures predict future bad events?". The Review of Financial Studies, 30 (7): 2313-2358.

Faleye, O., Kovacs, T. and Venkateswaran, A. 2014. "Do better-connected CEOs innovate more?". Journal of Financial and Quantitative Analysis, 49 (5-6): 1201-1225.

Fatemi, A.M. and Fooladi, I.J. 2013. "Sustainable finance: A new paradigm". Global Finance Journal, 24(2): 101-113.

Ferris, S.P., Javakhadze, D. and Rajkovic, T. 2017. “An international analysis of CEO social capital and corporate risk-taking”. European Financial Management. 25: 3-37.

Finkelstein, S. and D'aveni, R.A. 1994. "CEO duality as a double-edged sword: How boards of directors balance entrenchment avoidance and unity of command". Academy of Management journal, 37 (5): 1079-1108.,

Fracassi, C. and Tate, G. 2012. "External networking and internal firm governance". The Journal of Finance, 67 (1): 153-194.

Francoeur, C., Labelle, R., Balti, S. and Bouzaidi, S.E. 2019. "To what extent do gender diverse boards enhance corporate social performance?". Journal of Business Ethics: 1-15.

Freeman, L.C., 1977. "A set of measures of centrality based on betweenness. Sociometry": $35-41$. 
Goh, L., Liu, X. and Tsang, A. 2018. "Voluntary disclosure of corporate political spending". Journal of Corporate Finance, (In Press).

Goloshchapova, I., Poon, SH., Pritchardb, M. and Reed, P. 2019. “Corporate social responsibility reports: topic analysis and big data approach". The European Journal of Finance, (In Press).

Gompers, P., Ishii, J. and Metrick, A. 2003. "Corporate governance and equity prices". The Quarterly Journal of Economics, 118(1): 107-156.

Goss, A. and Roberts, G.S., 2011. "The impact of corporate social responsibility on the cost of bank loans". Journal of Banking and Finance, 35(7): 1794-1810.

Granovetter, M. 1973. "The strength of weak ties". American Journal of Sociology, 78(6): $1360-1380$

Gracia-Castro, R, Arino, M.A. and Canela, M.A., 2010. "Does social performance really lead to financial performance? Accounting for endogeneity". Journal of Business Ethics. 92(1): $107-126$

Hair, J.F., Black, W.C., Babin, B.J., Anderson, R.E., Tatham, R.L. (2010), Multivariate Data Analysis. $7^{\text {th }}$ ed. New York: Pearson.

Harjoto, M.; Laksmana, I.; and Lee, R., 2015. "Board diversity and corporate social responsibility", Journal of Business Ethics, 132 (4): 641-660.

Heemskerk, E.M. 2013. "The rise of the European corporate elite: evidence from the network of interlocking directorates in 2005 and 2010”. Economy and Society, 42(1): 74-101.

Hofstede, G. 1984. "Culture's consequences: International differences in work-related values. Sage". The GLOBE debate: Back to relevance. Journal of International Business Studies 41: 1339-46.

Hofstede, G., G. J. Hofstede, and M. Minkov. 2010. "Cultures and organizations: Software of the mind. Revised and expanded". McGraw-Hill, New York.

Hofstede, G. H., and G. Hofstede. 2001. "Culture's consequences: Comparing values, behaviors, institutions and organizations across nations". Sage.

Horton, J., Millo, Y. and Serafeim, G. 2012. "Resources or power? Implications of social networks on compensation and firm performance". Journal of Business Finance and Accounting, 39 (3-4): 399-426.

Intintoli, V.J., Kahle, K.M. and Zhao, W. 2018. "Director connectedness: Monitoring efficacy and career prospects". Journal of Financial and Quantitative Analysis, 53 (1): 65108. 
Ioannou, I. and Serafeim, G. 2015. "The impact of corporate social responsibility on investment recommendations: Analysts' perceptions and shifting institutional logics". Strategic Management Journal, 36 (7): 1053-1081.

Ioannou, I. and Serafeim, G. 2012. "What drives corporate social performance? The role of nation-level institiutions". Journal of International Business Studies 43: 834-864.

Janney, J.J. and Gove, S. 2011. "Reputation and corporate social responsibility aberrations, trends and hypocrisy: Reactions to firm choices in the stock option backdating scandal". Journal of Management Studies, 48(7): 1562-1585.

Jensen, M.C. 2002. "Value maximization, stakeholder theory, and the corporate objective function". Business Ethics Quarterly, 235-256.

Jo, H. and Harjoto, M.A. 2011. "Corporate governance and firm value: The impact of corporate social responsibility”. Journal of Business Ethics, 103 (3): 351-383.

Khwaja, A.I. and Mian, A. 2005. "Do lenders favor politically connected firms? Rent provision in an emerging financial market". The Quarterly Journal of Economics, 120 (4): $371-1411$

Klasa, S., Ortiz-Molina, H., Serfling, M., and Srinivasan, S. 2018. "Protection of trade secrets and capital structure decisions". Journal of Financial Economics, 128(2): 266-286.

Knyazeva, A., Knyazeva, D. and Masulis, R.W. 2013. "The supply of corporate directors and board independence". The Review of Financial Studies, 26 (6): 561-1605.

Konar, S. and Cohen, M.A. 2001. "Does the market value environmental performance?". Review of Economics and Statistics, 83 (2): 281-289.

Kruger, P., 2015. "Corporate Goodness and Shareholder Wealth”. Journal of Financial Economics, 115 (2): 304-329.

Larcker, D.F., So, E.C. and Wang, C.C. 2013. "Boardroom centrality and firm performance". Journal of Accounting and Economics, 55 (2-3): 225-250.

Lins, K.V., Servaes, H. and Tamayo, A. 2017. "Social capital, trust, and firm performance: The value of corporate social responsibility during the financial crisis". The Journal of Finance, 72 (4): 1785-1824.

Liu, S. and Wu, D. 2016. "Competing by conducting good deeds: The peer effect of corporate social responsibility”. Finance Research Letters, 16: 47-54.

Lys, T., Naughton, J.P. and Wang, C., 2015. "Signaling through corporate accountability reporting”. Journal of Accounting and Economics, 60(1): 56-72.

Maignan, I. and Ferrell, O.C. 2004. "Corporate social responsibility and marketing: An integrative framework". Journal of the Academy of Marketing Science, 32 (1): 3-19. 
Mason, C. and Simmons, J. 2014. "Embedding corporate social responsibility in corporate governance: A stakeholder systems approach”. Journal of Business Ethics, 119 (1): 77-86.

Masulis, R.W. and Mobbs, S. 2014. "Independent director incentives: Where do talented directors spend their limited time and energy?". Journal of Financial Economics, 111 (2): 406-429.

McElroy, K.M. and Siegfried, J.J. 1985. "The effect of firm size on corporate philanthropy". Quarterly Review of Economics and Business, 25 (2): 18-26.

Miranda-Lopez, J., Orlova, S. and Sun, L. 2018. "CEO network centrality and corporate cash holdings". Review of Quantitative Finance and Accounting, 1-37.

Naughton, J.P., Wang, C. and Yeung, I. 2018. "Investor Sentiment for Corporate Social Performance". The Accounting Review. (In Press)

Omer, T.C., Shelley, M.K. and Tice, F.M. 2019. "Do director networks matter for financial reporting quality? Evidence from audit committee connectedness and restatements".

Management Science (Forthcoming).

Ostgaard, T.A. and Birley, S. 1994. "Personal networks and firm competitive strategy-a strategic or coincidental match?”. Journal of Business Venturing, 9 (4): 281-305.

Proctor, C.H. and Loomis, C.P., 1951. "Analysis of sociometric data". Research methods in social relations, 2: 561-585.

Renneboog, L. and Zhao, Y. 2014. "Director networks and takeovers". Journal of Corporate Finance, 28: 218-234.

Renneboog, L. and Zhao, Y. 2011. "Us knows us in the UK: On director networks and CEO compensation”. Journal of Corporate Finance, 17: 1132-1157.

Rossi, A.G., Blake, D., Timmermann, A., Tonks, I. and Wermers, R. 2018. "Network centrality and delegated investment performance". Journal of Financial Economics, 128 (1): 183-206.

Servaes, H. and Tamayo, A. 2013. "The impact of corporate social responsibility on firm value: The role of customer awareness”. Management Science, 59 (5): 1045-1061.

Singh, D. and Delios, A. 2017. "Corporate governance, board networks and growth in domestic and international markets: Evidence from India". Journal of World Business, 52 (5): 615-627.

Vithessonthi, C., Schwaninger, M., and Müller, M.O. 2017. "Monetary policy, bank lending and corporate investment". International Review of Financial Analysis, 50: 129-142.

Walls, J.L., Berrone, P. and Phan, P.H. 2012. "Corporate governance and environmental performance: Is there really a link?”. Strategic Management Journal, 33 (8): 885-913. 
Yuan, Y., Tian, G., Lu, L.Y. and Yu, Y. 2017. "CEO ability and corporate social responsibility”. Journal of Business Ethics,1-21. 
Table 1-Panel A: Summary statistics of main variables

\begin{tabular}{|c|c|c|c|c|c|c|c|}
\hline & $\mathrm{p} 1$ & $1^{\text {st }}$ Quartile & Mean & Median & $3^{\text {rd }}$ Quartile & St.Dev & $\mathrm{p} 99$ \\
\hline Environmental Score (ES) & 9.19 & 20.07 & 53.865 & 56.6 & 86.09 & 31.413 & 95.35 \\
\hline Social Score (SS) & 5.98 & 29.97 & 56.806 & 60.94 & 84.00 & 28.827 & 96.56 \\
\hline Degree Centrality & .017 & 0.271 & .514 & .52 & 0.7575 & .283 & .989 \\
\hline Closeness Centrality & .011 & 0.2281 & .48 & .473 & 0.7208 & .289 & .97 \\
\hline Betweenness Centrality & 25 & 406.0 & 833.598 & 778 & 1220.0 & 512.2 & 1916 \\
\hline Eigenvector Centrality & .017 & 0.2710 & .513 & .519 & 0.7551 & .282 & .99 \\
\hline Firm Size & 79209 & 2.26806 & 8.62608 & 7713931 & 3.96607 & 1.03001 & 1.530110 \\
\hline Leverage & -441.08 & 20.78 & 112.766 & 53.91 & 109.82 & 1991.154 & 1233.07 \\
\hline $\mathrm{ROE}$ & -81.1 & 6.40 & 15.706 & 13.09 & 21.80 & 215.392 & 136.51 \\
\hline Liquidity & -.143 & 0.04 & .094 & .087 & 0.137 & .235 & .369 \\
\hline Duality & 0 & 0.00 & .195 & 0 & 0.000 & .396 & 1 \\
\hline G-index & 0 & 0.07 & .306 & .308 & 0.538 & .225 & .769 \\
\hline Inflation & -.356 & 1.465 & 2.581 & 2.27 & 3.226 & 2.05 & 10.882 \\
\hline GDP & 2.011 & 1.574 & 9.112 & 1.113 & 1.551 & 7.012 & 1.913 \\
\hline PDI & 22 & 40.00 & 46.113 & 40 & 40.00 & 15.277 & 104 \\
\hline INDI & 20 & 89.00 & 77.582 & 91 & 91.00 & 23.845 & 91 \\
\hline MAS & 34 & 61.00 & 63.293 & 62 & 62.00 & 10.608 & 95 \\
\hline UAI & 8 & 46.00 & 49.165 & 46 & 51.00 & 16.09 & 92 \\
\hline LTO & 21.159 & 25.693 & 36.696 & 25.693 & 43.829 & 20.3 & 87.909 \\
\hline IVR & 23.661 & 63.000 & 62.571 & 68.08 & 68.080 & 13.412 & 74.554 \\
\hline
\end{tabular}

Notes: Table 1 Panel A reports descriptive statistics on the variables used in our regressions. The sample includes 19,721 firm-year observations representing 2,023 firms over the period 2003-2018. Degree (Number of all direct links of each director with other directors), closeness (inverse of the sum of shortest distance between the focal director and all other directors), betweenness (probability that a director lies on the shortest path between any other two directors), eigenvector (the influence of a director in a network), ROE (ratio of net income to book value on equity), firm size (industry adjusted natural logarithm of total assets), leverage (total debt divided by percentage of common equity), liquidity (net sales divided by net receivables), duality (equals to 1 when a CEO or member of the executive board also the chairman of the board, and 0 otherwise), G-index (a governance index to capture firm-level investor protection). National culture is represented by PDI (Power distance), INDI (Individualism), MAS (Masculinity), UAI (Uncertainty avoidance), LTO (Long-term orientation), IVR (Indulgence versus Restraint). Refer to Appendix A for detailed definitions for all the variables used in this study.

\section{Panel B: Summary statistics by country}

\begin{tabular}{lrrrrrr}
\hline Country & Mean ES & Median ES & Mean SS & $\begin{array}{l}\text { Median } \\
\text { SS }\end{array}$ & $\begin{array}{l}\text { Number } \\
\text { of Firms }\end{array}$ & $\begin{array}{l}\text { Number of } \\
\text { Industries }\end{array}$ \\
\hline Australia & 41.185 & 31.65 & 44.557 & 41.18 & 286 & 35 \\
Brazil & 59.704 & 67.26 & 68.091 & 82.81 & 54 & 27 \\
Chile & 57.404 & 60.59 & 59.743 & 71.19 & 17 & 12 \\
China & 42.105 & 33.905 & 37.644 & 31.38 & 69 & 29 \\
Egypt & 30.072 & 14 & 33.797 & 27.465 & 8 & 5 \\
India & 64.303 & 73.38 & 66.263 & 74.14 & 73 & 26 \\
Indonesia & 64.488 & 69.76 & 75.364 & 82.065 & 21 & 12 \\
Israel & 39.693 & 23.01 & 44.837 & 32.38 & 11 & 9 \\
Japan & 80.892 & 91.4 & 72.226 & 82.695 & 324 & 38 \\
Malaysia & 56.999 & 61.935 & 64.408 & 73.055 & 39 & 14 \\
Mexico & 43.583 & 49.38 & 48.562 & 52.13 & 18 & 12 \\
New Zealand & 48.628 & 51.305 & 48.701 & 51.84 & 9 & 12 \\
Philippines & 53.346 & 58.91 & 56.445 & 58.95 & 19 & 12 \\
Singapore & 49.506 & 48.785 & 52.798 & 55.16 & 46 & 26 \\
South Africa & 60.415 & 66.28 & 75.279 & 83 & 115 & 31 \\
Thailand & 73.129 & 83.03 & 78.97 & 87.435 & 16 & 11 \\
United Kingdom & 62.639 & 68.58 & 65.641 & 72.62 & 152 & 37 \\
United States & 50.206 & 47.42 & 53.924 & 55.77 & 748 & 42 \\
\hline
\end{tabular}

Notes: Table 1 Panel B reports descriptive statistics of the countries in this study. The sample includes 17 countries, 2,023 firms over the period 2003-2018. 
Table 2: Correlation Matrix

\begin{tabular}{|c|c|c|c|c|c|c|c|c|c|c|c|c|c|c|c|c|c|c|c|c|}
\hline Variables & 番 & is & 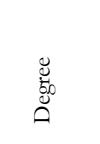 & 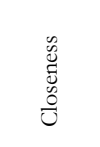 & 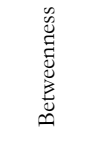 & 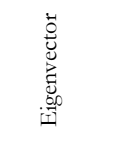 & $\begin{array}{l}\tilde{N} \\
\tilde{N} \\
\tilde{E}\end{array}$ & 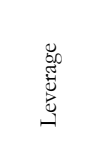 & $\begin{array}{l}\text { w1 } \\
\stackrel{1}{0}\end{array}$ & 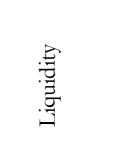 & 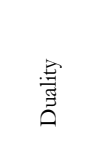 & 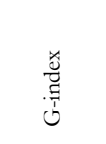 & 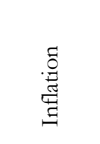 & (િ) & $\vec{a}$ & $\overline{\mathrm{Z}}$ & $\frac{n}{3}$ & 志 & f. & $\stackrel{s}{3}$ \\
\hline ES & $1.0000^{\mathrm{a}}$ & $0.7870^{\mathrm{a}}$ & $0.4278^{a}$ & $0.1267^{a}$ & $0.4133^{a}$ & $0.4001^{\mathrm{a}}$ & $0.4413^{a}$ & $0.1399^{\mathrm{a}}$ & $0.0504^{\mathrm{a}}$ & $0.0440^{\mathrm{a}}$ & $-0.0310^{a}$ & -0.0085 & $-0.1360^{a}$ & $0.0138^{c}$ & $0.1119^{\mathrm{a}}$ & $-0.1511^{a}$ & $0.1766^{a}$ & $0.0702^{a}$ & $0.2646^{\mathrm{a}}$ & $-0.1710^{a}$ \\
\hline ss & $0.7877^{a}$ & $1.0000^{a}$ & $0.4548^{a}$ & $0.1814^{a}$ & $0.4207 \mathrm{a}$ & $0.4237^{a}$ & $0.3978^{a}$ & $0.1052^{a}$ & $0.1267 \mathrm{a}$ & $0.1258^{a}$ & $-0.0395^{a}$ & $0.0177^{\mathrm{a}}$ & -0.0923 a & $0.0265^{a}$ & $0.0938^{a}$ & -0.1077 a & 0.0973 a & $0.0292^{a}$ & $0.2167 \mathrm{a}$ & $-0.1373 a$ \\
\hline Degree & $0.4189^{a}$ & $0.4504^{a}$ & $1.0000^{\mathrm{a}}$ & $0.1056^{a}$ & $0.8345^{\mathrm{a}}$ & $0.9677^{a}$ & $0.5175^{\mathrm{a}}$ & $0.1267^{a}$ & $0.0877^{a}$ & 0.0089 & $-0.1001^{a}$ & $-0.1873^{a}$ & $0.0485^{a}$ & $-0.1829^{a}$ & $0.1471^{a}$ & $-0.2204^{a}$ & $0.0635^{\mathrm{a}}$ & $0.0385^{\mathrm{a}}$ & $0.2461^{\mathrm{a}}$ & $-0.1776^{a}$ \\
\hline Closeness & $0.1184^{a}$ & $0.1706^{a}$ & $0.0834^{\mathrm{a}}$ & $1.0000^{\mathrm{a}}$ & 0.0029 & $-0.0444^{a}$ & $-0.1153^{a}$ & $0.0856^{\mathrm{a}}$ & $0.1561^{\mathrm{a}}$ & $0.1013^{\mathrm{a}}$ & $-0.0621^{a}$ & $0.4453^{a}$ & $-0.1844^{a}$ & $0.5971^{\mathrm{a}}$ & $-0.3665^{a}$ & $0.5260^{\mathrm{a}}$ & $0.4123^{a}$ & $-0.4243^{a}$ & $0.0235^{\mathrm{c}}$ & $0.2210^{\mathrm{a}}$ \\
\hline Betweenness & $0.4215^{a}$ & $0.4230^{\mathrm{a}}$ & $0.8320^{a}$ & $-0.0348^{a}$ & $1.0000 \mathrm{a}$ & $0.8385^{a}$ & $0.5883^{a}$ & $0.1273^{a}$ & $0.0181^{c}$ & $-0.0300^{a}$ & $-0.0767 \mathrm{a}$ & $-0.0700^{a}$ & $-0.0598^{a}$ & $-0.1395^{a}$ & $0.3281 \mathrm{a}$ & $-0.3039 a$ & $-0.0437 \mathrm{a}$ & $0.1745^{a}$ & $0.2407 \mathrm{a}$ & $-0.3148 a$ \\
\hline Eigenvector & $0.3890^{a}$ & $0.4170^{\mathrm{a}}$ & $0.9669 \mathrm{a}$ & $-0.0659 \mathrm{a}$ & $0.8358^{a}$ & $1.0000^{\mathrm{a}}$ & $0.5522 \mathrm{a}$ & $0.1187 \mathrm{a}$ & $0.0634^{a}$ & 0.0105 & $-0.1065^{a}$ & $-0.1800^{a}$ & $0.0643^{a}$ & $-0.1853^{a}$ & $0.2451 \mathrm{a}$ & $-0.2040^{a}$ & $-0.0404 a$ & $0.1376^{a}$ & $0.1666^{a}$ & $-0.2377 \mathrm{a}$ \\
\hline Firm Size & $0.0838^{a}$ & $0.0838^{a}$ & $0.0856^{a}$ & $-0.1011^{a}$ & $0.1220^{\mathrm{a}}$ & $0.0917^{\mathrm{a}}$ & $1.0000^{\mathrm{a}}$ & $0.2630^{\mathrm{a}}$ & $-0.0590^{a}$ & $-0.1669^{a}$ & $-0.0265^{b}$ & $-0.1421^{a}$ & $-0.0339^{a}$ & $-0.0128^{\mathrm{a}}$ & $0.6091^{a}$ & $-0.2895^{a}$ & $0.1611^{a}$ & $0.1337^{a}$ & $0.4613^{a}$ & $-0.6241^{a}$ \\
\hline Leverage & -0.0030 & -0.0077 & 0.0004 & 0.0062 & -0.0011 & 0.0010 & 0.0061 & $1.0000^{\mathrm{a}}$ & -0.0046 & $-0.2547 \mathrm{a}$ & -0.0072 & $0.0516^{\mathrm{a}}$ & $-0.0294^{a}$ & $0.0967^{\mathrm{a}}$ & $0.0781^{a}$ & $0.0264^{c}$ & $0.0236^{c}$ & $-0.0630^{a}$ & $0.0647 \mathrm{a}$ & $-0.0826^{a}$ \\
\hline ROE & 0.0056 & 0.0116 & 0.0130 & $0.0209^{c}$ & 0.0096 & 0.0087 & -0.0023 & -0.0150 & $1.0000^{\mathrm{a}}$ & $0.4719^{a}$ & $-0.0481^{a}$ & 0.0001 & $0.1268^{a}$ & $0.0696^{\mathrm{a}}$ & $-0.0239 c$ & 0.1021 a & $-0.0185^{c}$ & $-0.1820^{a}$ & -0.0010 & 0.0127 \\
\hline Liquidity & $0.0179 \mathrm{c}$ & $0.0804 \mathrm{a}$ & 0.0015 & $0.0727 \mathrm{a}$ & $-0.0271 \mathrm{a}$ & 0.0006 & -0.0088 & -0.0205 & 0.0765 a & $1.0000^{\mathrm{a}}$ & $-0.0471^{a}$ & $0.0823^{a}$ & $0.0210^{c}$ & $0.1067 \mathrm{a}$ & -0.0101 & $0.1360^{\mathrm{a}}$ & -0.0082 & $-0.0492^{a}$ & $-0.0499 \mathrm{a}$ & 0.0125 \\
\hline Duality & $-0.0304 \mathrm{a}$ & $-0.0395^{a}$ & $-0.1010^{a}$ & $-0.0640^{a}$ & $-0.0747^{a}$ & $-0.1075^{a}$ & $0.0229^{c}$ & -0.0015 & -0.0017 & $-0.0306^{a}$ & $1.0000^{\mathrm{a}}$ & $-0.0710^{a}$ & 0.0069 & $-0.0961^{a}$ & -0.0104 & $-0.1040^{a}$ & -0.0077 & $0.0160^{\mathrm{b}}$ & $0.0413^{\mathrm{a}}$ & $0.0190^{\mathrm{b}}$ \\
\hline$G$-index & 0.0050 & $0.0225^{\mathrm{a}}$ & $-0.1909^{a}$ & $0.4702^{a}$ & $-0.0736^{a}$ & $-0.1823^{a}$ & $-0.0828^{a}$ & $0.0155^{c}$ & -0.0065 & $0.0482^{\mathrm{a}}$ & $-0.0712^{a}$ & $1.0000^{\mathrm{a}}$ & $-0.3631^{a}$ & $0.7121^{a}$ & $-0.1169^{a}$ & $0.6276^{\mathrm{a}}$ & $0.0802^{a}$ & $-0.0676^{a}$ & $-0.3184^{a}$ & $0.0935^{a}$ \\
\hline Inflation & $-0.0733^{a}$ & -0.0395 a & $0.0913^{\mathrm{a}}$ & -0.2305 a & $0.0441^{a}$ & $0.1123 a$ & $0.0308^{a}$ & -0.0041 & 0.0061 & 0.0109 & 0.0100 & $-0.3403^{a}$ & $1.0000^{\mathrm{a}}$ & $-0.3041^{a}$ & $0.0557 \mathrm{a}$ & $-0.1186^{a}$ & $-0.3305^{a}$ & $-0.1258^{a}$ & $-0.0650^{\mathrm{a}}$ & $0.0162^{c}$ \\
\hline GDP & $-0.0462^{a}$ & $-0.0264^{a}$ & $-0.1978^{a}$ & $0.5715^{a}$ & $-0.1921^{a}$ & $-0.1768^{a}$ & $-0.1091^{a}$ & $0.0179^{\mathrm{b}}$ & 0.0069 & $0.0775^{a}$ & $-0.1062^{a}$ & $0.7042^{a}$ & $-0.2849^{a}$ & $1.0000^{a}$ & 0.0081 & $0.7923^{a}$ & $0.3423^{a}$ & $-0.1228^{a}$ & $-0.1812^{a}$ & $-0.0940^{\mathrm{a}}$ \\
\hline $\begin{array}{l}\text { PDI } \\
\text { PDI }\end{array}$ & $0.0779^{\mathrm{a}}$ & $0.0664^{\mathrm{a}}$ & $0.1612^{\mathrm{a}}$ & $-0.5141^{\text {a }}$ & $0.3183^{\mathrm{a}}$ & $0.2233^{a}$ & $0.1442^{\mathrm{a}}$ & -0.0029 & $\begin{array}{r}-0.0018 \\
\end{array}$ & $-0.0264^{a}$ & $0.0401^{\mathrm{a}}$ & $-0.3595^{\text {a }}$ & $0.3570^{\mathrm{a}}$ & $-0.4040^{a}$ & $1.0000^{\mathrm{a}}$ & $-0.3311^{\text {a }}$ & $-0.0630^{\mathrm{a}}$ & $0.0233^{c}$ & $0.5050^{\mathrm{a}}$ & $-0.9306^{a}$ \\
\hline INDI & $-0.1412^{a}$ & $-0.1024^{a}$ & $-0.2044^{a}$ & $0.5620^{\mathrm{a}}$ & $-0.3678^{a}$ & $-0.2517^{a}$ & $-0.2161^{a}$ & 0.0055 & 0.0046 & $0.0500^{\mathrm{a}}$ & $-0.0607 \mathrm{a}$ & $0.4560^{\mathrm{a}}$ & $-0.2291^{a}$ & $0.5214^{a}$ & $-0.9057^{a}$ & $1.0000^{\mathrm{a}}$ & $0.0443^{a}$ & $-0.0490^{\mathrm{a}}$ & $-0.6093^{a}$ & $0.3047^{a}$ \\
\hline MAS & $0.2085 \mathrm{a}$ & $0.1104 \mathrm{a}$ & $0.1487 \mathrm{a}$ & $\begin{aligned} & 0.0226^{c}\end{aligned}$ & $0.1738^{a}$ & $0.1244 \mathrm{a}$ & $0.0535 \mathrm{a}$ & $\begin{array}{l}-0.0027 \\
\end{array}$ & $\begin{array}{r}0.0040 \\
-0.0079\end{array}$ & -0.0659 a & -0.0033 & $\begin{array}{r}0.0601^{\mathrm{a}} \\
-0.0\end{array}$ & $\begin{array}{l}-0.3697 \mathrm{a} \\
-0.36\end{array}$ & -0.0118 & $\begin{array}{l}-0.1370 \text { a } \\
-0.137\end{array}$ & $\begin{array}{r}1.0568^{\mathrm{a}} \\
\end{array}$ & $1.0000^{\mathrm{a}}$ & $\begin{array}{l}-0.00870 \mathrm{a} \\
-0.0836^{2}\end{array}$ & $\begin{array}{r}-0.4597 \mathrm{a} \\
0\end{array}$ & $\begin{array}{r}0.1043 \\
-0.104\end{array}$ \\
\hline UAI & $0.1991^{\mathrm{a}}$ & $0.1398^{\mathrm{a}}$ & $0.1503^{\mathrm{a}}$ & $-0.2997 \mathrm{a}$ & $0.2746^{a}$ & $0.1986^{a}$ & $0.1464^{a}$ & -0.0017 & $-0.0175^{c}$ & $-0.0448^{a}$ & $0.0263^{a}$ & $-0.1435^{a}$ & $-0.1392^{a}$ & $-0.1339^{a}$ & $0.0216^{a}$ & $-0.2189^{a}$ & $0.6336^{a}$ & $1.0000^{\mathrm{a}}$ & $-0.2897 \mathrm{a}$ & $0.0746^{a}$ \\
\hline LTO & $0.2393^{\mathrm{a}}$ & $0.1558^{a}$ & $0.2451^{a}$ & $-0.2807 \mathrm{a}$ & $0.3177^{a}$ & $0.2119^{\mathrm{a}}$ & & -0.0067 & -0.0012 & $-0.0794^{a}$ & $0.0499 \mathrm{a}$ & $-0.4109^{a}$ & $-0.0273^{a}$ & $-0.4322^{a}$ & $0.5310^{\mathrm{a}}$ & & & $0.3222^{\mathrm{a}}$ & $1.0000^{a}$ & $-0.6783^{a}$ \\
\hline IVR & $-0.1652^{a}$ & $-0.1027^{a}$ & $-0.2202^{a}$ & $0.4276^{\mathrm{a}}$ & -0.3587 a & $-0.2605 \mathrm{a}$ & $-0.1809 \mathrm{a}$ & 0.0023 & 0.0018 & $0.0611^{\mathrm{a}}$ & $-0.0161 \mathrm{c}$ & $0.3250^{\mathrm{a}}$ & $-0.2437 \mathrm{a}$ & $0.3074 a$ & $-0.7211^{\mathrm{a}}$ & $0.7884^{\mathrm{a}}$ & $\begin{array}{r}-0.2705 \text { a } \\
\text { e }\end{array}$ & $-0.1539 a$ & $-0.8004^{a}$ & $1.0000^{\mathrm{a}}$ \\
\hline
\end{tabular}

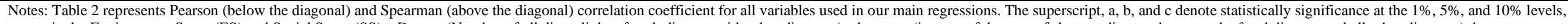

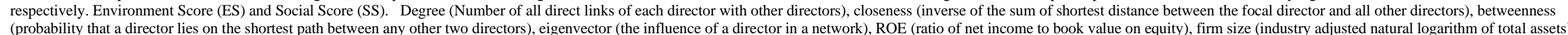

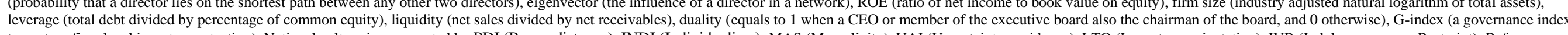

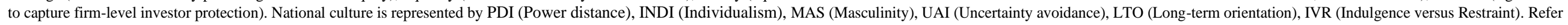
Appendix A for detailed definition for all the variables used in this study. 
Table 3 - Panel A: Impact of director's networks on environment score

\begin{tabular}{|c|c|c|c|c|c|c|c|c|c|c|c|c|}
\hline \multicolumn{13}{|c|}{ Dependent Variable $=$ ES } \\
\hline & $\begin{array}{l}\text { (1) } \\
\text { OLS }\end{array}$ & (2) & (3) & (4) & (5) & (6) & (7) & (8) & (9) & (10) & (11) & (12) \\
\hline Degree & & Prais Winsten & Newey West & OLS & Prais Winsten & Newey West & OLS & Prais Winsten & Newey West & OLS & Prais Winsten & Newey West \\
\hline Degree & $\begin{array}{r}44.8765^{* * * *} \\
(0.8190)\end{array}$ & $\begin{array}{r}44.8847 * * * \\
(0.8191)\end{array}$ & $\begin{array}{r}44.8765 * * * \\
(0.8190)\end{array}$ & & & & & & & & & \\
\hline Closeness & & & & $\begin{array}{r}48.6541 * * * * \\
(2.1829)\end{array}$ & $\begin{array}{r}48.6496 * * * \\
(2.1833)\end{array}$ & $\begin{array}{r}48.6541 * * * * \\
(2.1829)\end{array}$ & & & & & & \\
\hline Betweenness & & & & & & & $\begin{array}{r}0.0242 * * * \\
(0.0005)\end{array}$ & $\begin{array}{r}0.0242 * * * \\
(0.0005)\end{array}$ & $\begin{array}{r}0.0242 * * * \\
(0.0005)\end{array}$ & & & \\
\hline Eigenvector & & & & & & & & & & $\begin{array}{r}45.6698 * * * * \\
(0.8197)\end{array}$ & $\begin{array}{r}45.6771 * * * \\
(0.8197)\end{array}$ & $\begin{array}{r}45.6698 * * * \\
(0.8197)\end{array}$ \\
\hline ROE & $\begin{array}{r}0.0004 \\
(0.0014)\end{array}$ & $\begin{array}{r}0.0004 \\
(0.0014)\end{array}$ & $\begin{array}{r}0.0004 \\
(0.0014)\end{array}$ & $\begin{array}{r}0.0008 \\
(0.0017)\end{array}$ & $\begin{array}{r}0.0008 \\
(0.0017)\end{array}$ & $\begin{array}{r}0.0008 \\
(0.0017)\end{array}$ & $\begin{array}{r}0.0002 \\
(0.0017)\end{array}$ & $\begin{array}{r}0.0002 \\
(0.0017)\end{array}$ & $\begin{array}{r}0.0002 \\
(0.0017)\end{array}$ & $\begin{array}{r}0.0005 \\
(0.0014)\end{array}$ & $\begin{array}{r}0.0005 \\
(0.0014)\end{array}$ & $\begin{array}{r}0.0005 \\
(0.0014)\end{array}$ \\
\hline G-index & $\begin{array}{r}7.8852^{* * * *} \\
(2.0358)\end{array}$ & $\begin{array}{r}7.8614 * * * \\
(2.0367)\end{array}$ & $\begin{array}{r}7.8852 * * * \\
(2.0358)\end{array}$ & $\begin{array}{r}13.4830^{* * * *} \\
(2.1653)\end{array}$ & $\begin{array}{r}13.4788^{* * * *} \\
(2.1656)\end{array}$ & $\begin{array}{r}13.4830 * * * \\
(2.1653)\end{array}$ & $\begin{array}{r}9.2264 * * * \\
(2.0587)\end{array}$ & $\begin{array}{r}9.2084 * * * \\
(2.0594)\end{array}$ & $\begin{array}{r}9.2264 * * * \\
(2.0587)\end{array}$ & $\begin{array}{r}7.2386^{* * *} \\
(2.0348)\end{array}$ & $\begin{array}{r}7.2140^{* * * *} \\
(2.0358)\end{array}$ & $\begin{array}{r}7.2386^{* * * *} \\
(2.0348)\end{array}$ \\
\hline Leverage & $\begin{array}{r}-0.0001 \\
(0.0001)\end{array}$ & $\begin{array}{r}-0.0001 \\
(0.0001)\end{array}$ & $\begin{array}{r}-0.0001 \\
(0.0001)\end{array}$ & $\begin{array}{r}-0.0000 \\
(0.0001)\end{array}$ & $\begin{array}{r}-0.0000 \\
(0.0001)\end{array}$ & $\begin{array}{r}-0.0000 \\
(0.0001)\end{array}$ & $\begin{array}{r}-0.0000 \\
(0.0001)\end{array}$ & $\begin{array}{r}-0.0000 \\
(0.0001)\end{array}$ & $\begin{array}{r}-0.0000 \\
(0.0001)\end{array}$ & $\begin{array}{r}-0.0001 \\
(0.0001)\end{array}$ & $\begin{array}{r}-0.0001 \\
(0.0001)\end{array}$ & $\begin{array}{l}-0.0001 \\
(0.0001)\end{array}$ \\
\hline Firm Size & $\begin{array}{r}0.0000 \\
(0.0000)\end{array}$ & $\begin{array}{r}0.0000 \\
(0.0000)\end{array}$ & $\begin{array}{r}0.0000 \\
(0.0000)\end{array}$ & $\begin{array}{r}0.0000 \text { **** } \\
(0.0000)\end{array}$ & $\begin{array}{r}0.0000 \text { **** } \\
(0.0000)\end{array}$ & $\begin{array}{r}0.0000 * * * \\
(0.0000)\end{array}$ & $\begin{array}{r}0.0000 \\
(0.0000)\end{array}$ & $\begin{array}{r}0.0000 \\
(0.0000)\end{array}$ & $\begin{array}{r}0.0000 \\
(0.0000)\end{array}$ & $\begin{array}{r}0.0000 \\
(0.0000)\end{array}$ & $\begin{array}{r}0.0000 \\
(0.0000)\end{array}$ & $\begin{array}{r}0.0000 \\
(0.0000)\end{array}$ \\
\hline Inflation & $\begin{array}{r}-0.2435 \\
(0.2225)\end{array}$ & $\begin{array}{r}-0.2432 \\
(0.2240)\end{array}$ & $\begin{array}{l}-0.2435 \\
(0.2225)\end{array}$ & $\begin{array}{r}-0.2412 \\
(0.2354)\end{array}$ & $\begin{array}{r}-0.2408 \\
(0.2358)\end{array}$ & $\begin{array}{r}-0.2412 \\
(0.2354)\end{array}$ & $\begin{array}{l}-0.2027 \\
(0.2227)\end{array}$ & $\begin{array}{r}-0.2022 \\
(0.2238)\end{array}$ & $\begin{array}{r}-0.2027 \\
(0.2227)\end{array}$ & $\begin{array}{r}-0.2698 \\
(0.2227)\end{array}$ & $\begin{array}{r}-0.2694 \\
(0.2242)\end{array}$ & $\begin{array}{r}-0.2698 \\
(0.2227)\end{array}$ \\
\hline GDP & $\begin{array}{r}0.0000 * * * * \\
(0.0000)\end{array}$ & $\begin{array}{r}0.0000 * * * \\
(0.0000)\end{array}$ & $\begin{array}{r}0.0000 * * * \\
(0.0000)\end{array}$ & $\begin{array}{r}0.0000^{* * * *} \\
(0.0000)\end{array}$ & $\begin{array}{r}0.0000 * * * * \\
(0.0000)\end{array}$ & $\begin{array}{r}0.0000 * * * \\
(0.0000)\end{array}$ & $\begin{array}{r}0.0000 * * * \\
(0.0000)\end{array}$ & $\begin{array}{r}0.0000 * * * * \\
(0.0000)\end{array}$ & $\begin{array}{r}0.0000 * * * * \\
(0.0000)\end{array}$ & $\begin{array}{r}0.0000 * * * \\
(0.0000)\end{array}$ & $\begin{array}{r}0.0000 * * * * \\
(0.0000)\end{array}$ & $\begin{array}{r}0.0000 * * * * \\
(0.0000)\end{array}$ \\
\hline PDI & $\begin{array}{r}0.4139 \\
(0.4259)\end{array}$ & $\begin{array}{r}0.4137 \\
(0.4280)\end{array}$ & $\begin{array}{r}0.4139 \\
(0.4259)\end{array}$ & $\begin{array}{r}2.3997 * * * * \\
(0.4449)\end{array}$ & $\begin{array}{r}2.4007 * * * * \\
(0.4455)\end{array}$ & $\begin{array}{r}2.3997 * * * \\
(0.4449)\end{array}$ & $\begin{array}{c}0.8009^{*} \\
(0.4281)\end{array}$ & $\begin{array}{c}0.8017^{*} \\
(0.4296)\end{array}$ & $\begin{array}{c}0.8009^{*} \\
(0.4281)\end{array}$ & $\begin{array}{r}0.2769 \\
(0.4228)\end{array}$ & $\begin{array}{r}0.2768 \\
(0.4249)\end{array}$ & $\begin{array}{r}0.2769 \\
(0.4228)\end{array}$ \\
\hline INDI & $\begin{array}{r}0.7813 \\
(0.7067)\end{array}$ & $\begin{array}{r}0.7803 \\
(0.7104)\end{array}$ & $\begin{array}{r}0.7813 \\
(0.7067)\end{array}$ & $\begin{array}{r}3.8727 * * * * \\
(0.7383)\end{array}$ & $\begin{array}{r}3.8739 * * * * \\
(0.7393)\end{array}$ & $\begin{array}{r}3.8727 * * * \\
(0.7383)\end{array}$ & $\begin{array}{r}1.3948 * * \\
(0.7110)\end{array}$ & $\begin{array}{l}1.3955^{*} \\
(0.7137)\end{array}$ & $\begin{array}{r}1.3948 * * \\
(0.7110)\end{array}$ & $\begin{array}{r}0.5572 \\
(0.7016)\end{array}$ & $\begin{array}{r}0.5563 \\
(0.7053)\end{array}$ & $\begin{array}{r}0.5572 \\
(0.7016)\end{array}$ \\
\hline MAS & $\begin{array}{r}-2.1504 \\
(1.5028)\end{array}$ & $\begin{array}{r}-2.1486 \\
(1.5108)\end{array}$ & $\begin{array}{r}-2.1504 \\
(1.5028)\end{array}$ & $\begin{array}{r}-9.2784 * * * \\
(1.5773)\end{array}$ & $\begin{array}{r}-9.2813 * * * \\
(1.5797)\end{array}$ & $\begin{array}{r}-9.2784 * * * \\
(1.5773)\end{array}$ & $\begin{array}{r}-3.5781 * * \\
(1.5133)\end{array}$ & $\begin{array}{r}-3.5803 * * \\
(1.5193)\end{array}$ & $\begin{array}{r}-3.5781 * * \\
(1.5133)\end{array}$ & $\begin{array}{r}-1.6202 \\
(1.4930)\end{array}$ & $\begin{array}{r}-1.6189 \\
(1.5013)\end{array}$ & $\begin{array}{r}-1.6202 \\
(1.4930)\end{array}$ \\
\hline UAI & $\begin{array}{c}0.9855^{*} \\
(0.5257)\end{array}$ & $\begin{array}{c}0.9853^{*} \\
(0.5285)\end{array}$ & $\begin{array}{l}0.9855^{*} \\
(0.5257)\end{array}$ & $\begin{array}{r}3.6316^{* * * * *} \\
(0.5524)\end{array}$ & $\begin{array}{r}3.6327 * * * * \\
(0.5532)\end{array}$ & $\begin{array}{r}3.6316^{* * * *} \\
(0.5524)\end{array}$ & $\begin{array}{r}1.4833^{* * * *} \\
(0.5293)\end{array}$ & $\begin{array}{r}1.4845^{* * * *} \\
(0.5314)\end{array}$ & $\begin{array}{r}1.4833^{* * * *} \\
(0.5293)\end{array}$ & $\begin{array}{r}0.8063 \\
(0.5224)\end{array}$ & $\begin{array}{r}0.8063 \\
(0.5252)\end{array}$ & $\begin{array}{r}0.8063 \\
(0.5224)\end{array}$ \\
\hline LTO & $\begin{array}{r}1.6497 \\
(1.1527)\end{array}$ & $\begin{array}{r}1.6474 \\
(1.1588)\end{array}$ & $\begin{array}{r}1.6497 \\
(1.1527)\end{array}$ & $\begin{array}{r}7.1762^{* * * *} \\
(1.2106)\end{array}$ & $\begin{array}{r}7.1781 * * * \\
(1.2124)\end{array}$ & $\begin{array}{r}7.1762 * * * \\
(1.2106)\end{array}$ & $\begin{array}{r}2.7526^{* * *} \\
(1.1609)\end{array}$ & $\begin{array}{r}2.7536^{* * *} \\
(1.1655)\end{array}$ & $\begin{array}{r}2.7526 * * \\
(1.1609)\end{array}$ & $\begin{array}{r}1.2256 \\
(1.1452)\end{array}$ & $\begin{array}{r}1.2236 \\
(1.1516)\end{array}$ & $\begin{array}{r}1.2256 \\
(1.1452)\end{array}$ \\
\hline IVR & $\begin{array}{r}0.7539 \\
(0.7135)\end{array}$ & $\begin{array}{r}0.7520 \\
(0.7174)\end{array}$ & $\begin{array}{r}0.7539 \\
(0.7135)\end{array}$ & $\begin{array}{r}4.0442^{* * * *} \\
(0.7520)\end{array}$ & $\begin{array}{r}4.0452 * * * \\
(0.7532)\end{array}$ & $\begin{array}{r}4.0442 * * * \\
(0.7520)\end{array}$ & $\begin{array}{r}1.4478^{* *} \\
(0.7192)\end{array}$ & $\begin{array}{r}1.4480^{* * *} \\
(0.7221)\end{array}$ & $\begin{array}{r}1.4478 * * \\
(0.7192)\end{array}$ & $\begin{array}{r}0.4653 \\
(0.7089)\end{array}$ & $\begin{array}{r}0.4636 \\
(0.7129)\end{array}$ & $\begin{array}{r}0.4653 \\
(0.7089)\end{array}$ \\
\hline Constant & $\begin{array}{r}-96.0265 \\
(91.7421) \\
\end{array}$ & $\begin{array}{r}-95.8490 \\
(92.2144) \\
\end{array}$ & $\begin{array}{r}-96.0265 \\
(91.7421) \\
\end{array}$ & $\begin{array}{r}-495.2927 * * * * \\
(96.3455) \\
\end{array}$ & $\begin{array}{r}-495.4460 * * * * \\
(96.4847)\end{array}$ & $\begin{array}{r}-495.2927 * * * \\
(96.3455) \\
\end{array}$ & $\begin{array}{r}-166.6760^{*} \\
(92.3741) \\
\end{array}$ & $\begin{array}{r}-166.7397^{*} \\
(92.7300) \\
\end{array}$ & $\begin{array}{r}-166.6760^{*} \\
(92.3741) \\
\end{array}$ & $\begin{array}{r}-65.4358 \\
(91.0981) \\
\end{array}$ & $\begin{array}{r}-65.2823 \\
(91.5872) \\
\end{array}$ & $\begin{array}{r}-65.4358 \\
(91.0981) \\
\end{array}$ \\
\hline Observations & 14965 & 14965 & 14965 & 14965 & 14,965 & 14965 & 14965 & 14965 & 14965 & 14965 & 14965 & 14965 \\
\hline Adj R'squared & 0.291 & 0.289 & n.a. & 0.193 & 0.192 & n.a & 0.269 & 0.267 & n.a & 0.293 & 0.290 & n.a. \\
\hline Year FE & Yes & Yes & Yes & Yes & Yes & Yes & Yes & Yes & Yes & Yes & Yes & Yes \\
\hline Industry FE & Yes & Yes & Yes & Yes & Yes & Yes & Yes & Yes & Yes & Yes & Yes & Yes \\
\hline
\end{tabular}

Notes. Table 3 Panel A provides the results of the regressions of director's networks on ES (Environment Score) and other firm characteristics using different estimation techniques: OLS, Prais Winsten, and Newey W

The dependent variable is Environment Score (ES). Degree (Number of all direct links of each director with other directors), closeness (inverse of the sum of shortest distance between the focal director and all other directs), betwe board also the chairman of the board, and 0 otherwise), G-index (a governance index to capture firm-level investor protection). National culture is represented by PDI (Power distance), INDI (Individualism), MAS

(Masculinity), UAI (Uncertainty avoidance), LTO (Long-term orientation), IVR (Indulgence versus Restraint). All reported t-values in parentheses are based on robust standard errors adjusted for clustering by firm *, **,

**** refer to significance at the $10 \%, 5 \%$, and $1 \%$ levels, respectively. 
Panel B: Impact of director's networks on social score

\begin{tabular}{|c|c|c|c|c|c|c|c|c|c|c|c|c|}
\hline \multicolumn{13}{|c|}{ Dependent Variable = SS } \\
\hline & (1) & $(2)$ & (3) & (4) & $(5)$ & (6) & (7) & $(8)$ & (9) & (10) & $(11)$ & (12) \\
\hline & OLS & Prais Winsten & Newey West & OLS & Prais Winsten & Newey West & OLS & Prais Winsten & Newey West & OLS & Prais Winsten & Newey West \\
\hline Degree & $\begin{array}{r}46.5605^{* * * *} \\
(0.7198)\end{array}$ & $\begin{array}{r}46.5635^{* * * *} \\
(0.7198)\end{array}$ & $\begin{array}{r}46.5605^{* * *} \\
(0.7198)\end{array}$ & & & & & & & & & \\
\hline Closeness & & & & $\begin{array}{r}54.8888 * * * \\
(2.0238)\end{array}$ & $\begin{array}{r}54.8882 * * * \\
(2.0238)\end{array}$ & $\begin{array}{r}54.8888 * * * \\
(2.0238)\end{array}$ & & & & & & \\
\hline Betweenness & & & & & & & $\begin{array}{r}0.0246 * * * * \\
(0.0004)\end{array}$ & $\begin{array}{r}0.0246 * * * * \\
(0.0004)\end{array}$ & $\begin{array}{r}0.0246 * * * \\
(0.0004)\end{array}$ & & & \\
\hline Eigenvector & & & & & & & & & & $\begin{array}{r}47.3420 * * * \\
(0.7268)\end{array}$ & $\begin{array}{r}47.3444 * * * \\
(0.7268)\end{array}$ & $\begin{array}{r}47.3420 * * * \\
(0.7268)\end{array}$ \\
\hline ROE & $\begin{array}{r}0.0010 \\
(0.0016)\end{array}$ & $\begin{array}{r}0.0010 \\
(0.0016)\end{array}$ & $\begin{array}{r}0.0010 \\
(0.0016)\end{array}$ & $\begin{array}{r}0.0013 \\
(0.0020)\end{array}$ & $\begin{array}{r}0.0013 \\
(0.0020)\end{array}$ & $\begin{array}{r}0.0013 \\
(0.0020)\end{array}$ & $\begin{array}{r}0.0008 \\
(0.0019)\end{array}$ & $\begin{array}{r}0.0008 \\
(0.0019)\end{array}$ & $\begin{array}{r}0.0008 \\
(0.0019)\end{array}$ & $\begin{array}{r}0.0010 \\
(0.0016)\end{array}$ & $\begin{array}{r}0.0010 \\
(0.0016)\end{array}$ & $\begin{array}{r}0.0010 \\
(0.0016)\end{array}$ \\
\hline G-index & $\begin{array}{r}12.3871 * * * \\
(1.8407)\end{array}$ & $\begin{array}{r}12.3838^{* * * *} \\
(1.8413)\end{array}$ & $\begin{array}{r}12.3871 \text { *** } \\
(1.8407)\end{array}$ & $\begin{array}{r}18.0423^{* * * *} \\
(1.9895)\end{array}$ & $\begin{array}{r}18.0425^{* * * *} \\
(1.9895)\end{array}$ & $\begin{array}{r}18.0423 * * * \\
(1.9895)\end{array}$ & $\begin{array}{r}13.9169 * * * \\
(1.8818)\end{array}$ & $\begin{array}{r}13.9150 \text { *** } \\
(1.8821)\end{array}$ & $\begin{array}{r}13.9169^{* * * *} \\
(1.8818)\end{array}$ & $\begin{array}{r}11.7235 * * * \\
(1.8396)\end{array}$ & $\begin{array}{r}11.7200 * * * \\
(1.8401)\end{array}$ & $\begin{array}{r}11.7235 * * * \\
(1.8396)\end{array}$ \\
\hline Leverage & $\begin{array}{r}-0.0001 * \\
(0.0001)\end{array}$ & $\begin{array}{r}-0.0001 * * \\
(0.0001)\end{array}$ & $\begin{array}{r}-0.0001 * \\
(0.0001)\end{array}$ & $\begin{array}{r}-0.0001 \\
(0.0001)\end{array}$ & $\begin{array}{r}-0.0001 \\
(0.0001)\end{array}$ & $\begin{array}{r}-0.0001 \\
(0.0001)\end{array}$ & $\begin{array}{r}-0.0001 \\
(0.0001)\end{array}$ & $\begin{array}{r}-0.0001 \\
(0.0001)\end{array}$ & $\begin{array}{r}-0.0001 \\
(0.0001)\end{array}$ & $\begin{array}{r}-0.0001 * \\
(0.0001)\end{array}$ & $\begin{array}{r}-0.0001 * \\
(0.0001)\end{array}$ & $\begin{array}{r}-0.0001 * \\
(0.0001)\end{array}$ \\
\hline Firm Size & $\begin{array}{r}0.0000 \\
(0.0000)\end{array}$ & $\begin{array}{r}0.0000 \\
(0.0000)\end{array}$ & $\begin{array}{r}0.0000 \\
(0.0000)\end{array}$ & $\begin{array}{r}0.0000^{* * * *} \\
(0.0000)\end{array}$ & $\begin{array}{r}0.0000^{* * * *} \\
(0.0000)\end{array}$ & $\begin{array}{r}0.0000 * * * \\
(0.0000)\end{array}$ & $\begin{array}{r}0.0000 \\
(0.0000)\end{array}$ & $\begin{array}{r}0.0000 \\
(0.0000)\end{array}$ & $\begin{array}{r}0.0000 \\
(0.0000)\end{array}$ & $\begin{array}{r}0.0000 \\
(0.0000)\end{array}$ & $\begin{array}{r}0.0000 \\
(0.0000)\end{array}$ & $\begin{array}{r}0.0000 \\
(0.0000)\end{array}$ \\
\hline Inflation & $\begin{array}{r}-0.2507 \\
(0.2114)\end{array}$ & $\begin{array}{r}-0.2504 \\
(0.2124)\end{array}$ & $\begin{array}{r}-0.2507 \\
(0.2114)\end{array}$ & $\begin{array}{r}-0.2433 \\
(0.2258)\end{array}$ & $\begin{array}{r}-0.2432 \\
(0.2259)\end{array}$ & $\begin{array}{r}-0.2433 \\
(0.2258)\end{array}$ & $\begin{array}{r}-0.2106 \\
(0.2133)\end{array}$ & $\begin{array}{r}-0.2103 \\
(0.2139)\end{array}$ & $\begin{array}{r}-0.2106 \\
(0.2133)\end{array}$ & $\begin{array}{r}-0.2781 \\
(0.2117)\end{array}$ & $\begin{array}{r}-0.2776 \\
(0.2128)\end{array}$ & $\begin{array}{r}-0.2781 \\
(0.2117)\end{array}$ \\
\hline GDP & $\begin{array}{r}0.0000 \\
(0.0000)\end{array}$ & $\begin{array}{r}0.0000 \\
(0.0000)\end{array}$ & $\begin{array}{r}0.0000 \\
(0.0000)\end{array}$ & $\begin{array}{r}-0.0000 \\
(0.0000)\end{array}$ & $\begin{array}{r}-0.0000 \\
(0.0000)\end{array}$ & $\begin{array}{r}-0.0000 \\
(0.0000)\end{array}$ & $\begin{array}{r}0.0000 * * * \\
(0.0000)\end{array}$ & $\begin{array}{r}0.0000 * * * \\
(0.0000)\end{array}$ & $\begin{array}{r}0.0000 * * * \\
(0.0000)\end{array}$ & $\begin{array}{r}0.0000 \\
(0.0000)\end{array}$ & $\begin{array}{r}0.0000 \\
(0.0000)\end{array}$ & $\begin{array}{r}0.0000 \\
(0.0000)\end{array}$ \\
\hline PDI & $\begin{array}{r}-0.9126 * * \\
(0.3784)\end{array}$ & $\begin{array}{r}-0.9134 * * \\
(0.3798)\end{array}$ & $\begin{array}{r}-0.9126 * * \\
(0.3784)\end{array}$ & $\begin{array}{r}1.2074 * * * \\
(0.3925)\end{array}$ & $\begin{array}{r}1.2075^{* * *} * \\
(0.3926)\end{array}$ & $\begin{array}{r}1.2074 * * * \\
(0.3925)\end{array}$ & $\begin{array}{r}-0.4891 \\
(0.3782)\end{array}$ & $\begin{array}{r}-0.4891 \\
(0.3789)\end{array}$ & $\begin{array}{r}-0.4891 \\
(0.3782)\end{array}$ & $\begin{array}{r}-1.0534 * * * \\
(0.3769)\end{array}$ & $\begin{array}{r}-1.0542 * * * \\
(0.3785)\end{array}$ & $\begin{array}{r}-1.0534 * * * \\
(0.3769)\end{array}$ \\
\hline INDI & $\begin{array}{r}-1.4756 * * \\
(0.6238)\end{array}$ & $\begin{array}{r}-1.4774 * * \\
(0.6263)\end{array}$ & $\begin{array}{r}-1.4756 * * \\
(0.6238)\end{array}$ & $\begin{array}{r}1.8278 * * * \\
(0.6393)\end{array}$ & $\begin{array}{r}1.8279^{* * * *} \\
(0.6395)\end{array}$ & $\begin{array}{r}1.8278 * * * \\
(0.6393)\end{array}$ & $\begin{array}{r}-0.8061 \\
(0.6232)\end{array}$ & $\begin{array}{r}-0.8063 \\
(0.6244)\end{array}$ & $\begin{array}{r}-0.8061 \\
(0.6232)\end{array}$ & $\begin{array}{r}-1.7061 * * * * \\
(0.6217)\end{array}$ & $\begin{array}{r}-1.7078^{* * * *} \\
(0.6244)\end{array}$ & $\begin{array}{r}-1.7061 * * * \\
(0.6217)\end{array}$ \\
\hline MAS & $\begin{array}{r}2.7221 * * \\
(1.3193)\end{array}$ & $\begin{array}{r}2.7256^{* *} \\
(1.3247)\end{array}$ & $\begin{array}{r}2.7221 * * \\
(1.3193)\end{array}$ & $\begin{array}{r}-4.8981 * * * \\
(1.3600)\end{array}$ & $\begin{array}{r}-4.8984 * * * \\
(1.3602)\end{array}$ & $\begin{array}{r}-4.8981 * * * * \\
(1.3600)\end{array}$ & $\begin{array}{r}1.1659 \\
(1.3212)\end{array}$ & $\begin{array}{r}1.1659 \\
(1.3239)\end{array}$ & $\begin{array}{r}1.1659 \\
(1.3212)\end{array}$ & $\begin{array}{r}3.2674 * * \\
(1.3156)\end{array}$ & $\begin{array}{r}3.2708^{* * *} \\
(1.3216)\end{array}$ & $\begin{array}{r}3.2674 * * \\
(1.3156)\end{array}$ \\
\hline UAI & $\begin{array}{c}-0.8075^{*} \\
(0.4615)\end{array}$ & $\begin{array}{r}-0.8085^{*} \\
(0.4634)\end{array}$ & $\begin{array}{c}-0.8075^{*} \\
(0.4615)\end{array}$ & $\begin{array}{r}2.0200 * * * \\
(0.4771)\end{array}$ & $\begin{array}{r}2.0201 * * * \\
(0.4772)\end{array}$ & $\begin{array}{r}2.0200^{* * * *} \\
(0.4771)\end{array}$ & $\begin{array}{r}-0.2621 \\
(0.4623)\end{array}$ & $\begin{array}{r}-0.2620 \\
(0.4632)\end{array}$ & $\begin{array}{r}-0.2621 \\
(0.4623)\end{array}$ & $\begin{array}{r}-0.9918 * * \\
(0.4603)\end{array}$ & $\begin{array}{r}-0.9926 * * \\
(0.4624)\end{array}$ & $\begin{array}{r}-0.9918^{* *} \\
(0.4603)\end{array}$ \\
\hline LTO & $\begin{array}{r}-2.2825^{* *} \\
(1.0105)\end{array}$ & $\begin{array}{r}-2.2858^{* *} \\
(1.0146)\end{array}$ & $\begin{array}{r}-2.2825 * * \\
(1.0105)\end{array}$ & $\begin{array}{r}3.6305^{* * *} \\
(1.0423)\end{array}$ & $\begin{array}{r}3.6307 * * * \\
(1.0425)\end{array}$ & $\begin{array}{r}3.6305 * * * \\
(1.0423)\end{array}$ & $\begin{array}{r}-1.0813 \\
(1.0121)\end{array}$ & $\begin{array}{r}-1.0817 \\
(1.0142)\end{array}$ & $\begin{array}{r}-1.0813 \\
(1.0121)\end{array}$ & $\begin{array}{r}-2.7189^{* * *} \\
(1.0076)\end{array}$ & $\begin{array}{r}-2.7222 * * * * \\
(1.0122)\end{array}$ & $\begin{array}{r}-2.7189^{* * * *} \\
(1.0076)\end{array}$ \\
\hline IVR & $\begin{array}{r}-1.5771 * * \\
(0.6175)\end{array}$ & $\begin{array}{r}-1.5796^{* *} \\
(0.6200)\end{array}$ & $\begin{array}{r}-1.5771 * * \\
(0.6175)\end{array}$ & $\begin{array}{r}1.9508 * * * \\
(0.6381)\end{array}$ & $\begin{array}{r}1.9509 * * * \\
(0.6382)\end{array}$ & $\begin{array}{r}1.9508 * * * \\
(0.6381)\end{array}$ & $\begin{array}{r}-0.8260 \\
(0.6190)\end{array}$ & $\begin{array}{r}-0.8265 \\
(0.6202)\end{array}$ & $\begin{array}{r}-0.8260 \\
(0.6190)\end{array}$ & $\begin{array}{r}-1.8743^{* * * *} \\
(0.6158)\end{array}$ & $\begin{array}{r}-1.8769 * * * \\
(0.6186)\end{array}$ & $\begin{array}{r}-1.8743 * * * \\
(0.6158)\end{array}$ \\
\hline Constant & $\begin{array}{r}215.5549 * * * \\
(80.3203) \\
\end{array}$ & $\begin{array}{r}215.8289^{* * *} \\
(80.6402) \\
\end{array}$ & $\begin{array}{r}215.5549 * * * \\
(80.3203) \\
\end{array}$ & $\begin{array}{r}-213.2620^{* *} \\
(83.0498) \\
\end{array}$ & $\begin{array}{r}-213.2748 * * \\
(83.0657) \\
\end{array}$ & $\begin{array}{r}-213.2620^{* * *} \\
(83.0498) \\
\end{array}$ & $\begin{array}{r}138.3477^{*} \\
(80.3962)\end{array}$ & $\begin{array}{r}138.3891 * \\
(80.5550)\end{array}$ & $\begin{array}{r}138.3477^{*} \\
(80.3962)\end{array}$ & $\begin{array}{r}247.0481 * * * \\
(80.0536) \\
\end{array}$ & $\begin{array}{r}247.3229 * * * * \\
(80.4057) \\
\end{array}$ & $\begin{array}{r}247.0481^{* * * *} \\
(80.0536) \\
\end{array}$ \\
\hline Observations & 14965 & 14965 & 14965 & 14965 & 14965 & 14965 & 14965 & 14965 & 14965 & 14965 & 14965 & 14965 \\
\hline Adj R'squared & 0.329 & 0.328 & n.a & 0.212 & 0.211 & n.a & 0.294 & 0.293 & n.a & 0.330 & 0.329 & n.a. \\
\hline Year FE & Yes & Yes & Yes & Yes & Yes & Yes & Yes & Yes & Yes & Yes & Yes & Yes \\
\hline Industry FE & Yes & Yes & Yes & Yes & Yes & Yes & Yes & Yes & Yes & Yes & Yes & Yes \\
\hline
\end{tabular}


Table 4: The quasi-natural experiment: Difference-in-differences (DiD) analysis for the effect of financial crisis

\begin{tabular}{|c|c|c|c|c|c|c|c|c|}
\hline & \multicolumn{2}{|c|}{$\begin{array}{c}\text { De Haas et al. (2015) } \\
\text { Financial Crisis: 2008-2011 }\end{array}$} & \multicolumn{2}{|c|}{$\begin{array}{c}\text { Cull and Peria (2013) } \\
\text { Financial Crisis: 2007-2008 }\end{array}$} & \multicolumn{2}{|c|}{$\begin{array}{c}\text { Bertrand and Mullainathan (2003) } \\
\text { Parallel Trends Test }\end{array}$} & \multicolumn{2}{|c|}{$\begin{array}{c}\text { Falsification tests } \\
\text { Placebo Crisis }\end{array}$} \\
\hline & (1) & (2) & (3) & (4) & (5) & (6) & (7) & (8) \\
\hline & ES & SS & ES & SS & ES & SS & ES & SS \\
\hline Strong Conn & $\begin{array}{c}13.4081^{* * *} \\
(0.7830)\end{array}$ & $\begin{array}{c}14.2319^{* * *} \\
(0.6853)\end{array}$ & $\begin{array}{c}6.7698^{* * *} \\
(1.5082)\end{array}$ & $\begin{array}{c}11.0202 * * * \\
(1.5222)\end{array}$ & & & & \\
\hline Year 2008 & $\begin{array}{c}3.6925 \\
(2.6737)\end{array}$ & $\begin{array}{c}3.7221 \\
(2.6283)\end{array}$ & & & & & & \\
\hline Year 2009 & $\begin{array}{l}-2.1356 \\
(2.5017)\end{array}$ & $\begin{array}{l}-3.0045 \\
(2.4968)\end{array}$ & & & & & & \\
\hline Year 2010 & $\begin{array}{l}-4.0699 * \\
(2.4556)\end{array}$ & $\begin{array}{l}-4.3989^{*} \\
(2.4277)\end{array}$ & & & & & & \\
\hline Year 2011 & $\begin{array}{l}-3.9567 \\
(2.5103)\end{array}$ & $\begin{array}{l}-3.8541 \\
(2.4634)\end{array}$ & & & & & & \\
\hline Year 2008 x Strong Conn & $\begin{array}{c}-4.7534 * * \\
(2.2545)\end{array}$ & $\begin{array}{l}-2.0635 \\
(2.0747)\end{array}$ & & & & & & \\
\hline Year 2009 x Strong Conn & $\begin{array}{c}0.9407 \\
(2.0250)\end{array}$ & $\begin{array}{c}0.8502 \\
(1.8930)\end{array}$ & & & & & & \\
\hline Year 2010 x Strong Conn & $\begin{array}{l}3.3126^{*} \\
(1.8763)\end{array}$ & $\begin{array}{l}2.4573 \\
(1.7063)\end{array}$ & & & & & & \\
\hline Year 2011 x Strong Conn & $\begin{array}{c}5.2218^{* * *} \\
(1.7997)\end{array}$ & $\begin{array}{l}3.0689^{*} \\
(1.6328)\end{array}$ & & & & & & \\
\hline Post-Crisis & & & $\begin{array}{c}7.1873 * * \\
(2.8930)\end{array}$ & $\begin{array}{c}13.1136^{* * *} \\
(2.8517)\end{array}$ & $\begin{array}{l}-2.9996 \\
(2.8936)\end{array}$ & $\begin{array}{l}-1.9662 \\
(2.6959)\end{array}$ & & \\
\hline Post-Crisis x Strong Conn & & & $\begin{array}{c}8.8139 * * * \\
(1.6325)\end{array}$ & $\begin{array}{c}4.0881 * * \\
(1.6078)\end{array}$ & & & & \\
\hline After $^{1}$ & & & & & $\begin{array}{l}6.7422^{* *} \\
(3.3616)\end{array}$ & $\begin{array}{c}2.9836 \\
(3.0245)\end{array}$ & & \\
\hline After ${ }^{2+}$ & & & & & $\begin{array}{l}8.0082 * * * \\
(2.9699)\end{array}$ & $\begin{array}{c}12.6072^{* * *} \\
(2.6538)\end{array}$ & & \\
\hline Before $^{1}$ & & & & & $\begin{array}{c}0.2684 \\
(2.6994)\end{array}$ & $\begin{array}{l}-1.4202 \\
(2.4181)\end{array}$ & & \\
\hline Before $^{2+}$ & & & & & $\begin{array}{l}-0.7322 \\
(2.3624)\end{array}$ & $\begin{array}{c}0.0622 \\
(2.0952)\end{array}$ & & \\
\hline Placebo (t-1) & & & & & & & $\begin{array}{l}-0.5923 \\
(2.6422)\end{array}$ & $\begin{array}{c}2.6264 \\
(2.4596)\end{array}$ \\
\hline Constant & $\begin{array}{l}-545.2359 * * * \\
(98.6848)\end{array}$ & $\begin{array}{l}-243.9058^{* * *} \\
(86.9617)\end{array}$ & $\begin{array}{c}-384.9269 * * * \\
(106.6991)\end{array}$ & $\begin{array}{l}-197.1750^{* *} \\
(94.6933)\end{array}$ & $\begin{array}{c}-801.7391 * * * \\
(160.6370)\end{array}$ & $\begin{array}{l}-200.2428 \\
(142.2594)\end{array}$ & $\begin{array}{c}-147.2738 \\
(1685.8363)\end{array}$ & $\begin{array}{l}-499.4954 \\
(1596.9520)\end{array}$ \\
\hline Observations & 14942 & 14942 & 12618 & 12618 & 8283 & 8283 & 782 & 782 \\
\hline R-squared & 0.1819 & 0.1884 & 0.1938 & 0.1999 & 0.1304 & 0.1530 & 0.0446 & 0.1048 \\
\hline All control variables & Included & Included & Included & Included & Included & Included & Included & Included \\
\hline Industry FE & Yes & Yes & Yes & Yes & Yes & Yes & Yes & Yes \\
\hline Year FE & Yes & Yes & Yes & Yes & Yes & Yes & Yes & Yes \\
\hline
\end{tabular}


Table 5: Addressing reverse causality in the relationship between director's network and CSR

\begin{tabular}{|c|c|c|c|c|c|c|c|c|}
\hline & (1) & (2) & (3) & (4) & (5) & (6) & (7) & (8) \\
\hline & ES & ES & ES & ES & SS & SS & SS & SS \\
\hline Degree & $\begin{array}{r}43.2717 * * * * \\
(0.8777)\end{array}$ & & & & $\begin{array}{r}43.3173 * * * \\
(0.7534)\end{array}$ & & & \\
\hline Closeness & & $\begin{array}{r}43.8797 * * * \\
(2.1687)\end{array}$ & & & & $\begin{array}{r}47.2167 * * * \\
(1.9248)\end{array}$ & & \\
\hline Betweenness & & & $\begin{array}{r}0.0237 * * * \\
(0.0005)\end{array}$ & & & & $\begin{array}{r}0.0229 * * * \\
(0.0005)\end{array}$ & \\
\hline Eigenvector & & & & $\begin{array}{r}43.9073^{* * * *} \\
(0.8778)\end{array}$ & & & & $\begin{array}{r}44.0074 * * * * \\
(0.7593)\end{array}$ \\
\hline $\begin{array}{l}\text { All control variables } \\
\text { Constant }\end{array}$ & $\begin{array}{r}\text { Included } \\
-58.7501 \\
(104.4234)\end{array}$ & $\begin{array}{r}\text { Included } \\
-339.7314^{* * *} \\
(110.2932)\end{array}$ & $\begin{array}{r}\text { Included } \\
-162.8917 \\
(105.6495)\end{array}$ & $\begin{array}{r}\text { Included } \\
-28.6175 \\
(103.8225)\end{array}$ & $\begin{array}{r}\text { Included } \\
339.8315^{* * * *} \\
(85.8691)\end{array}$ & $\begin{array}{r}\text { Included } \\
50.5251 \\
(90.7111)\end{array}$ & $\begin{array}{r}\text { Included } \\
232.9885^{* * * *} \\
(87.1357)\end{array}$ & $\begin{array}{r}\text { Included } \\
370.2462 * * * \\
(85.6221)\end{array}$ \\
\hline Observations & 13531 & 13531 & 13531 & 13531 & 13531 & 13531 & 13531 & 13531 \\
\hline R-squared & 0.2832 & 0.1915 & 0.2555 & 0.2841 & 0.3319 & 0.2242 & 0.2887 & 0.3334 \\
\hline Industry FE & Yes & Yes & Yes & Yes & Yes & Yes & Yes & Yes \\
\hline Year FE & Yes & Yes & Yes & Yes & Yes & Yes & Yes & Yes \\
\hline Country FE & Yes & Yes & Yes & Yes & Yes & Yes & Yes & Yes \\
\hline
\end{tabular}

Notes: Table 5 provides the results of the regressions of director's networks on ES an SS using 2-year lead value. The sample includes 19,72

firm year observations over the period 2003-2018. The dependent variable is Environment Score (ES) Social Score (SS). Degree (Number of

all direct links of each director with other directors), closeness (inverse of the sum of shortest distance between the focal director and all other directors), betweenness (probability that a director lies on the shortest path between any other two directors), eigenvector (the influence of a

director in a network). All control variables (as in Table 3A \& B) are included but not reported. All reported t-values in parentheses are based

on robust standard errors adjusted for clustering by firm. *,**,*** refer to significance at the $10 \%, 5 \%$, and $1 \%$ levels, respectively. 
$\underline{\text { Table } 6 \text {-Panel A: Impact of Centrality on CSR using 2SLS }}$

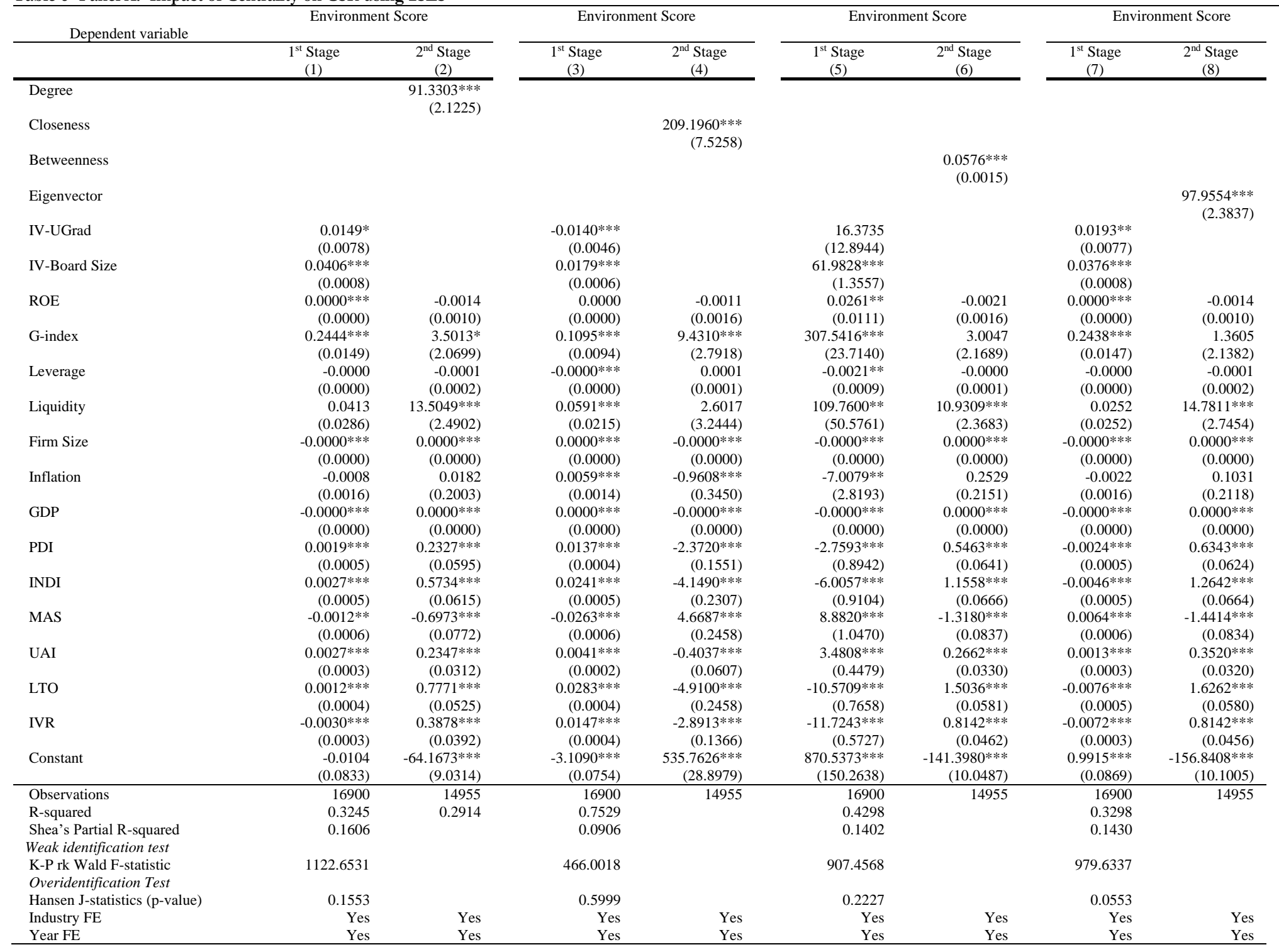


Notes: Table 6 Panel A provides the results of the regressions of director's networks on Environment score with other firm characteristics using 2SLS estimation techniques. The instruments used in this equation are: IV-UGrad and IV-Board Size. The dependent variable is Environment Score. Degree (Number of all direct links of each director with other directors), closeness (inverse of the sum of shortest distance between the focal director and all other directors), betweenness (probability that a director lies on the shortest path

between any other two directors), eigenvector (the influence of a director in a network), ROE (ratio of net income to book value on equity), firm size (industry adjusted natural logarithm of total assets), leverage (total debt divided by percentage of common equity), liquidity (net sales divided by net receivables), duality (equals to 1 when a CEO or member of the executive board also the chairman of the board, and 0 otherwise), G-index (a governance index to capture firm-level investor protection). National culture is represented by PDI (Power distance), INDI (Individualism), MAS (Masculinity), UAI (Uncertainty avoidance), LTO (Long-term orientation), IVR (Indulgence versus Restraint). K-P (Kleibergen-Paap) rk Wald F-statistic for weak instrument test and Hansen J-statistics for overidentification test are reported. All reported t-values in parentheses are based on robust standard errors adjusted for clustering by firm. *, **, *** refer to significance at the $10 \%, 5 \%$, and $1 \%$ levels, respectively. 
Panel B: Impact of Centrality on CSR using 2SLS

\begin{tabular}{|c|c|c|c|c|c|c|c|c|}
\hline \multirow[t]{2}{*}{ Dependent Variable } & \multicolumn{2}{|c|}{ Social Score } & \multicolumn{2}{|c|}{ Social Score } & \multicolumn{2}{|c|}{ Social Score } & \multicolumn{2}{|c|}{ Social Score } \\
\hline & $\begin{array}{c}1^{\text {st }} \text { Stage } \\
\text { (1) }\end{array}$ & $\begin{array}{l}2^{\text {nd }} \text { Stage } \\
(2)\end{array}$ & $\begin{array}{l}1^{\text {st }} \text { Stage } \\
\text { (3) }\end{array}$ & $\begin{array}{c}2^{\text {nd }} \text { Stage } \\
(4)\end{array}$ & $\begin{array}{c}1^{\text {st }} \text { Stage } \\
(5)\end{array}$ & $\begin{array}{c}2^{\text {nd }} \text { Stage } \\
(6)\end{array}$ & $\begin{array}{c}1^{\text {st }} \text { Stage } \\
(7)\end{array}$ & $\begin{array}{c}2^{\text {nd }} \text { Stage } \\
(8)\end{array}$ \\
\hline Degree & & $\begin{array}{r}85.7369^{* * *} \\
(1.8575)\end{array}$ & & & & & & \\
\hline Closeness & & & & $\begin{array}{r}196.0215^{* * * *} \\
(6.6416)\end{array}$ & & & & \\
\hline Betweenness & & & & & & $\begin{array}{r}0.0541 * * * \\
(0.0013)\end{array}$ & & \\
\hline Eigenvector & & & & & & & & $\begin{array}{r}91.9806 * * * \\
(2.1161)\end{array}$ \\
\hline IV-UGrad & $\begin{array}{l}0.0149 * \\
(0.0078)\end{array}$ & & $\begin{array}{r}-0.0140 * * * \\
(0.0046)\end{array}$ & & $\begin{array}{r}16.3735 \\
(12.8944)\end{array}$ & & $\begin{array}{r}0.0193 * * \\
(0.0077)\end{array}$ & \\
\hline IV-Board Size & $\begin{array}{r}0.0406 * * * \\
(0.0008)\end{array}$ & & $\begin{array}{r}0.0179^{* * * *} \\
(0.0006)\end{array}$ & & $\begin{array}{r}61.9828 * * * \\
(1.3557)\end{array}$ & & $\begin{array}{r}0.0376^{* * * *} \\
(0.0008)\end{array}$ & \\
\hline ROE & $\begin{array}{c}0.0000^{* * * *} \\
(0.0000)\end{array}$ & $\begin{array}{r}-0.0010 \\
(0.0010)\end{array}$ & $\begin{array}{r}0.0000 \\
(0.0000)\end{array}$ & $\begin{array}{r}-0.0008 \\
(0.0016)\end{array}$ & $\begin{array}{r}0.0261 * * \\
(0.0111)\end{array}$ & $\begin{array}{r}-0.0017 \\
(0.0015)\end{array}$ & $\begin{array}{r}0.0000 * * * * \\
(0.0000)\end{array}$ & $\begin{array}{r}-0.0011 \\
(0.0010)\end{array}$ \\
\hline G-index & $\begin{array}{r}0.2444 * * * \\
(0.0149)\end{array}$ & $\begin{array}{r}7.6979 * * * \\
(1.8849)\end{array}$ & $\begin{array}{r}0.1095^{* * * *} \\
(0.0094)\end{array}$ & $\begin{array}{r}13.2805^{* * * * *} \\
(2.5518)\end{array}$ & $\begin{array}{r}307.5416^{* * * * * *} \\
(23.7140)\end{array}$ & $\begin{array}{r}7.2326 * * * * \\
(1.9974)\end{array}$ & $\begin{array}{r}0.2438 * * * \\
(0.0147)\end{array}$ & $\begin{array}{r}5.6839^{* * * *} \\
(1.9486)\end{array}$ \\
\hline Leverage & $\begin{array}{r}-0.0000 \\
(0.0000)\end{array}$ & $\begin{array}{r}-0.0001 \\
(0.0001)\end{array}$ & $\begin{array}{r}-0.0000^{* * * *} \\
(0.0000)\end{array}$ & $\begin{array}{r}0.0000 \\
(0.0001)\end{array}$ & $\begin{array}{r}-0.0021^{* *} \\
(0.0009)\end{array}$ & $\begin{array}{r}-0.0000 \\
(0.0001)\end{array}$ & $\begin{array}{r}-0.0000 \\
(0.0000)\end{array}$ & $\begin{array}{r}-0.0001 \\
(0.0001)\end{array}$ \\
\hline Liquidity & $\begin{array}{r}0.0413 \\
(0.0286)\end{array}$ & $\begin{array}{r}21.2155^{* * * *} \\
(3.9526)\end{array}$ & $\begin{array}{r}0.0591 * * * \\
(0.0215)\end{array}$ & $\begin{array}{r}11.0023 * * * * \\
(2.9243)\end{array}$ & $\begin{array}{r}109.7600^{* * *} \\
(50.5761)\end{array}$ & $\begin{array}{r}18.7994 * * * * \\
(3.5889)\end{array}$ & $\begin{array}{r}0.0252 \\
(0.0252)\end{array}$ & $\begin{array}{r}22.4134^{* * * * *} \\
(4.2803)\end{array}$ \\
\hline Firm Size & $\begin{array}{r}-0.0000^{* * * *} * \\
(0.0000)\end{array}$ & $\begin{array}{r}0.0000 * * * \\
(0.0000)\end{array}$ & $\begin{array}{r}0.0000 * * * * \\
(0.0000)\end{array}$ & $\begin{array}{r}-0.0000^{* *} \\
(0.0000)\end{array}$ & $\begin{array}{r}-0.0000^{* * * *} \\
(0.0000)\end{array}$ & $\begin{array}{r}0.0000^{* * * *} \\
(0.0000)\end{array}$ & $\begin{array}{r}-0.0000^{* * * *} \\
(0.0000)\end{array}$ & $\begin{array}{r}0.0000^{* * * *} \\
(0.0000)\end{array}$ \\
\hline Inflation & $\begin{array}{r}-0.0008 \\
(0.0016)\end{array}$ & $\begin{array}{r}0.3134 \\
(0.1943)\end{array}$ & $\begin{array}{r}0.0059 * * * \\
(0.0014)\end{array}$ & $\begin{array}{r}-0.6034 * \\
(0.3244)\end{array}$ & $\begin{array}{r}-7.0079^{* *} * \\
(2.8193)\end{array}$ & $\begin{array}{r}0.5337^{* *} \\
(0.2089)\end{array}$ & $\begin{array}{r}-0.0022 \\
(0.0016)\end{array}$ & $\begin{array}{l}0.3931 * \\
(0.2051)\end{array}$ \\
\hline GDP & $\begin{array}{r}-0.0000^{* * * *} \\
(0.0000)\end{array}$ & $\begin{array}{r}0.0000^{* * * * *} \\
(0.0000)\end{array}$ & $\begin{array}{r}0.0000 * * * * \\
(0.0000)\end{array}$ & $\begin{array}{r}-0.0000^{* * * *} \\
(0.0000)\end{array}$ & $\begin{array}{r}-0.0000^{* * * *} *{ }^{2}(0.0000)\end{array}$ & $\begin{array}{r}0.0000 * * * * \\
(0.0000)\end{array}$ & $\begin{array}{r}-0.0000 * * * * \\
(0.0000)\end{array}$ & $\begin{array}{r}0.0000^{* * * *} \\
(0.0000)\end{array}$ \\
\hline PDI & $\begin{array}{r}0.0019 * * * \\
(0.0005)\end{array}$ & $\begin{array}{r}0.3979 * * * * \\
(0.0551)\end{array}$ & $\begin{array}{r}0.0137 * * * \\
(0.0004)\end{array}$ & $\begin{array}{r}-2.0423 * * * \\
(0.1392)\end{array}$ & $\begin{array}{r}-2.7593^{* * * *} \\
(0.8942)\end{array}$ & $\begin{array}{r}0.6924 * * * \\
(0.0591)\end{array}$ & $\begin{array}{r}-0.0024 * * * \\
(0.0005)\end{array}$ & $\begin{array}{r}0.7750^{* * * *} \\
(0.0581)\end{array}$ \\
\hline INDI & $\begin{array}{r}0.0027^{* * * *} \\
(0.0005)\end{array}$ & $\begin{array}{r}0.6721 * * * * \\
(0.0594)\end{array}$ & $\begin{array}{r}0.0241^{* * * *} \\
(0.0005)\end{array}$ & $\begin{array}{r}-3.7526^{* * * *} \\
(0.2072)\end{array}$ & $\begin{array}{r}-6.0057 * * * * \\
(0.9104)\end{array}$ & $\begin{array}{r}1.2188 * * * * \\
(0.0634)\end{array}$ & $\begin{array}{r}-0.0046 * * * * \\
(0.0005)\end{array}$ & $\begin{array}{r}1.3206 * * * * \\
(0.0634)\end{array}$ \\
\hline MAS & $\begin{array}{r}-0.0012^{* *} \\
(0.0006)\end{array}$ & $\begin{array}{r}-0.9794 * * * \\
(0.0799)\end{array}$ & $\begin{array}{r}-0.0263^{* * * *} \\
(0.0006)\end{array}$ & $\begin{array}{r}4.0485^{* * * *} \\
(0.2251)\end{array}$ & $\begin{array}{r}8.8820^{* * * *} \\
(1.0470)\end{array}$ & $\begin{array}{r}-1.5620^{* * * *} \\
(0.0845)\end{array}$ & $\begin{array}{r}0.0064 * * * \\
(0.0006)\end{array}$ & $\begin{array}{r}-1.6780^{* * * *} \\
(0.0840)\end{array}$ \\
\hline UAI & $\begin{array}{r}0.0027^{* * * *} \\
(0.0003)\end{array}$ & $\begin{array}{c}0.2628^{* * * * *} \\
(0.0322)\end{array}$ & $\begin{array}{r}0.0041^{* * * *} \\
(0.0002)\end{array}$ & $\begin{array}{r}-0.3350^{* * * *} \\
(0.0580)\end{array}$ & $\begin{array}{r}3.4808 * * * * \\
(0.4479)\end{array}$ & $\begin{array}{c}0.2924 * * * * \\
(0.0336)\end{array}$ & $\begin{array}{r}0.0013^{* * * *} \\
(0.0003)\end{array}$ & $\begin{array}{r}0.3728 * * * * \\
(2.0328)\end{array}$ \\
\hline LTO & $\begin{array}{r}0.0012^{* * * *} \\
(0.0004)\end{array}$ & $\begin{array}{r}0.8356 * * * * \\
(0.0512)\end{array}$ & $\begin{array}{r}0.0283^{* * * *} \\
(0.0004)\end{array}$ & $\begin{array}{r}-4.4930 * * * \\
(0.2209)\end{array}$ & $\begin{array}{r}-10.5709^{* * *} \\
(0.7658)\end{array}$ & $\begin{array}{r}1.5176^{* * * *} \\
(0.0557)\end{array}$ & $\begin{array}{r}-0.0076^{* * * *} \\
(0.0005)\end{array}$ & $\begin{array}{r}1.6329 * * * * \\
(0.0552)\end{array}$ \\
\hline IVR & $\begin{array}{r}-0.0030^{* * * *} \\
(0.0003)\end{array}$ & $\begin{array}{r}0.4991 * * * \\
(0.0374)\end{array}$ & $\begin{array}{r}0.0147 * * * * \\
(0.0004)\end{array}$ & $\begin{array}{r}-2.5740^{* * * *} \\
(0.1243)\end{array}$ & $\begin{array}{r}-11.7243 * * * * \\
(0.5727)\end{array}$ & $\begin{array}{r}0.8993 * * * * \\
(0.0436)\end{array}$ & $\begin{array}{r}-0.0072 * * * \\
(0.0003)\end{array}$ & $\begin{array}{r}0.8996 * * * \\
(0.0433)\end{array}$ \\
\hline Constant & $\begin{array}{r}-0.0104 \\
(0.0833)\end{array}$ & $\begin{array}{r}-66.1437 * * * \\
(7.9704)\end{array}$ & $\begin{array}{r}-3.1090^{* * * *} \\
(0.0754)\end{array}$ & $\begin{array}{r}496.0397 * * * \\
(26.2167)\end{array}$ & $\begin{array}{r}870.5373^{* * * *} \\
(150.2638)\end{array}$ & $\begin{array}{r}-138.6393 * * * \\
(9.2851)\end{array}$ & $\begin{array}{r}0.9915^{* * *} \\
(0.0869)\end{array}$ & $\begin{array}{r}-153.1696^{* * * *} \\
(8.9527)\end{array}$ \\
\hline Observations & 16900 & 14955 & 16900 & 14955 & 16900 & 14955 & 16900 & 14955 \\
\hline R-squared & 0.3245 & & 0.7529 & & 0.4298 & & 0.3298 & \\
\hline $\begin{array}{l}\text { Shea's Partial R-squared } \\
\text { Weak identification test }\end{array}$ & 0.1606 & & 0.0906 & & 0.1402 & & 0.1430 & \\
\hline $\begin{array}{l}\text { K-P rk Wald F-statistic } \\
\text { Overidentification Test }\end{array}$ & 1122.6531 & & 466.0018 & & 907.4568 & & 979.6337 & \\
\hline Hansen J-statistics (p-value) & 0.5476 & & 0.0099 & & 0.6594 & & 0.2550 & \\
\hline Industry FE & Yes & Yes & Yes & Yes & Yes & Yes & Yes & Yes \\
\hline Year FE & Yes & Yes & Yes & Yes & Yes & Yes & Yes & Yes \\
\hline
\end{tabular}


Notes: Table 6 Panel B provides the results of the regressions of director's networks on Social score with other firm characteristics using 2SLS estimation techniques. The instruments used in this equation are: UGrad and Board Size. The dependent variable is Social Score. Degree (Number of all direct links of each director with other directors), closeness (inverse of the sum of shortest distance between the focal director and all other directors), betweenness (probability that a director lies on the shortest path between any other two directors), eigenvector (the influence of a director in a network), ROE (ratio of net income to book value on equity), firm size (industry adjusted natural logarithm of total assets), leverage (total debt divided by percentage of common equity), liquidity (net sales divided by net receivables), duality (equals to 1 when a CEO or member of the executive board also the chairman of the board, and 0 otherwise), G-index (a governance index to capture firm-level investor protection). National culture is represented by PDI (Power distance), INDI (Individualism), MAS (Masculinity), UAI (Uncertainty avoidance), LTO (Long-term orientation), IVR (Indulgence versus Restraint). K-P (Kleibergen-Paap) rk Wald F-statistic for weak instrument test and Hansen J-statistics for overidentification test are reported. All reported t-values in parentheses are based on robust standard errors adjusted for clustering by firm. *, **, *** refer to significance at the $10 \%, 5 \%$, and $1 \%$ levels, respectively. 
Table 7: Robustness tests and addressing self-selection bias

Panel A: Dependent Variable: Environment Score

\begin{tabular}{|c|c|c|c|c|c|c|c|c|}
\hline . & \multicolumn{4}{|c|}{ 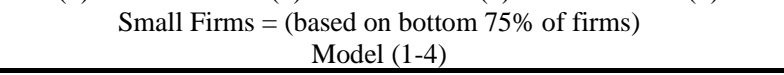 } & \multicolumn{4}{|c|}{ 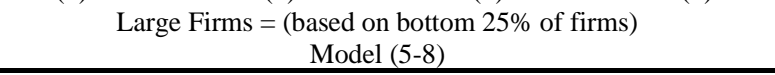 } \\
\hline Degree & $\begin{array}{r}26.9758^{* * *} \\
(1.1184)\end{array}$ & & & & $\begin{array}{r}8.8361 * * * \\
(1.9629)\end{array}$ & & & \\
\hline Closeness & & $\begin{array}{r}23.1992 * * * \\
(2.2281)\end{array}$ & & & & $\begin{array}{r}50.2515 * * * * \\
(3.8228)\end{array}$ & & \\
\hline Betweenness & & & $\begin{array}{r}0.0136 * * * \\
(0.0007)\end{array}$ & & & & $\begin{array}{r}0.0237 * * * \\
(0.0011)\end{array}$ & \\
\hline Eigenvector & & & & $\begin{array}{r}27.8854 * * * \\
(1.1311)\end{array}$ & & & & $\begin{array}{r}49.4362 * * * \\
(1.9819)\end{array}$ \\
\hline All control variables & Included & Included & Included & Included & Included & Included & Included & Included \\
\hline Constant & $\begin{array}{r}483.7106 * * * \\
(98.1094)\end{array}$ & $\begin{array}{r}344.6935 * * * \\
(98.5093)\end{array}$ & $\begin{array}{r}448.2046 * * * \\
(98.1935)\end{array}$ & $\begin{array}{r}515.3201 * * * \\
(97.7828)\end{array}$ & $\begin{array}{r}25.7975 \\
(33.6348)\end{array}$ & $\begin{array}{r}106.5690 * * * \\
(35.0068)\end{array}$ & $\begin{array}{r}54.6629 \\
(33.7517)\end{array}$ & $\begin{array}{r}14.3653 \\
(33.4546)\end{array}$ \\
\hline Observations & 11026 & 11026 & 11026 & 11026 & 3939 & 3939 & 3939 & 3939 \\
\hline $\mathrm{R}$-squared & 0.2530 & 0.2201 & 0.2406 & 0.2544 & 0.3294 & 0.2411 & 0.3039 & 0.3279 \\
\hline
\end{tabular}

Panel B- Dependent Variable-Social Score

\begin{tabular}{|c|c|c|c|c|c|c|c|c|}
\hline \multirow[t]{2}{*}{ 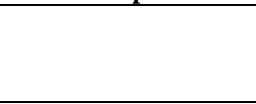 } & \multirow{2}{*}{\multicolumn{4}{|c|}{$\begin{array}{c}\text { Small Firms }=(\text { based on bottom } 75 \% \text { of firms }) \\
\text { Model }(1-4)\end{array}$}} & (5) & (6) & (7) & (8) \\
\hline & & & & & \multicolumn{4}{|c|}{$\begin{array}{c}\text { Large Firms }=(\text { based on bottom } 25 \% \text { of firms }) \\
\text { Model (5-8) }\end{array}$} \\
\hline Degree & $\begin{array}{r}34.3213 * * * \\
(1.0082)\end{array}$ & & & & $\begin{array}{r}47.2818 * * * \\
(1.7999)\end{array}$ & & & \\
\hline Closeness & & $\begin{array}{r}32.6298^{* * * *} \\
(2.1165)\end{array}$ & & & & $\begin{array}{r}57.2256 * * * \\
(3.5685)\end{array}$ & & \\
\hline Betweenness & & & $\begin{array}{r}0.0170 * * * \\
(0.0006)\end{array}$ & & & & $\begin{array}{r}0.0241 * * * \\
(0.0010)\end{array}$ & \\
\hline Eigenvector & & & & $\begin{array}{r}35.6943 * * * \\
(1.0253)\end{array}$ & & & & $\begin{array}{r}46.8669 * * * * \\
(1.8394)\end{array}$ \\
\hline All control variables & Included & Included & Included & Included & Included & Included & Included & Included \\
\hline Constant & $\begin{array}{r}714.4219 * * * * \\
(87.3665)\end{array}$ & $\begin{array}{r}533.6382^{* * * *} \\
(83.6929)\end{array}$ & $\begin{array}{r}667.5913 * * * * \\
(85.8201)\end{array}$ & $\begin{array}{r}755.7330^{* * * * *} \\
(86.6456)\end{array}$ & $\begin{array}{r}125.7076 * * * \\
(33.5399)\end{array}$ & $\begin{array}{r}209.2519 * * * \\
(35.0905)\end{array}$ & $\begin{array}{r}152.6919 * * * \\
(33.6597)\end{array}$ & $\begin{array}{r}115.8657^{* * * *} \\
(33.5386)\end{array}$ \\
\hline Observations & $\begin{array}{r}(07.5005) \\
11026\end{array}$ & $\begin{array}{r}(05.0929) \\
11026\end{array}$ & $\begin{array}{r}\text { (0J.0201) } \\
11026\end{array}$ & $\begin{array}{r}(00.0450) \\
11026\end{array}$ & $\begin{array}{r}(35.5399) \\
3939\end{array}$ & $\begin{array}{r}3939 \\
3939\end{array}$ & $\begin{array}{r}(30.0391) \\
3939\end{array}$ & $\begin{array}{r}\text { (J0.5300) } \\
3939\end{array}$ \\
\hline R-squared & 0.2812 & 0.1898 & 0.2611 & 0.2209 & 0.2987 & 0.2186 & 0.3254 & 0.3154 \\
\hline
\end{tabular}

to 
Table 7 Panel C: Impact of Centrality on CSR using 2SLS -with alternative measures of leverage and liquidity

\begin{tabular}{|c|c|c|c|c|c|c|c|c|}
\hline & \multicolumn{2}{|c|}{ Environment Score } & \multicolumn{2}{|c|}{ Environment Score } & \multicolumn{2}{|c|}{ Environment Score } & \multicolumn{2}{|c|}{ Environment Score } \\
\hline & $\begin{array}{l}1^{\text {st }} \text { Stage } \\
(1)\end{array}$ & $\begin{array}{l}2^{\text {nd }} \text { Stage } \\
\text { (2) }\end{array}$ & $\begin{array}{l}1^{\text {st }} \text { Stage } \\
\text { (3) }\end{array}$ & $\begin{array}{c}2^{\text {nd }} \text { Stage } \\
(4)\end{array}$ & $\begin{array}{l}1^{\text {st }} \text { Stage } \\
(5)\end{array}$ & $\begin{array}{l}2^{\text {nd }} \text { Stage } \\
(6)\end{array}$ & $\begin{array}{c}1^{\text {st }} \underset{(7)}{(7)} \\
\text { (age }\end{array}$ & $\begin{array}{l}2^{\text {nd }} \text { Stage } \\
(8)\end{array}$ \\
\hline Degree & & $\begin{array}{r}95.9197 * * * \\
(2.4949)\end{array}$ & & & & & & \\
\hline Closeness & & & & $\begin{array}{r}210.9776 * * * \\
(8.5138)\end{array}$ & & & & \\
\hline Betweenness & & & & & & $\begin{array}{r}0.0600 * * * \\
(0.0017)\end{array}$ & & \\
\hline Eigenvector & & & & & & & & $\begin{array}{r}103.2043 * * * \\
(2.8283)\end{array}$ \\
\hline IV-UGrad & $\begin{array}{c}0.0213 * * \\
(0.0084)\end{array}$ & & $\begin{array}{r}-0.0128 * * \\
(0.0050)\end{array}$ & & $\begin{array}{l}24.7951 * \\
(13.7597)\end{array}$ & & $\begin{array}{r}0.0250 * * * \\
(0.0083)\end{array}$ & \\
\hline IV-Board Size & $\begin{array}{r}0.0381 * * * \\
(0.0009)\end{array}$ & & $\begin{array}{r}0.0175^{* * * *} \\
(0.0006)\end{array}$ & & $\begin{array}{r}58.3866 * * * \\
(1.4906)\end{array}$ & & $\begin{array}{r}0.0352^{* * * *} \\
(0.0009)\end{array}$ & \\
\hline $\mathrm{ROA}$ & $\begin{array}{r}0.0000 * * * * \\
(0.0000)\end{array}$ & $\begin{array}{l}-0.0011 \\
(0.0012)\end{array}$ & $\begin{array}{r}0.0000 \\
(0.0000)\end{array}$ & $\begin{array}{l}-0.0011 \\
(0.0015)\end{array}$ & $\begin{array}{r}0.0272 * * \\
(0.0114)\end{array}$ & $\begin{array}{l}-0.0018 \\
(0.0017)\end{array}$ & $\begin{array}{r}0.0000 * * * \\
(0.0000)\end{array}$ & $\begin{array}{r}-0.0011 \\
(0.0012)\end{array}$ \\
\hline G-index & $\begin{array}{r}0.2335 * * * \\
(0.0160)\end{array}$ & $\begin{array}{l}3.7882^{*} \\
(2.2766)\end{array}$ & $\begin{array}{r}0.1068^{* * * *} \\
(0.0101)\end{array}$ & $\begin{array}{r}9.5734 * * * \\
(2.9725)\end{array}$ & $\begin{array}{r}258.1314 * * * \\
(25.5270)\end{array}$ & $\begin{array}{l}4.6033^{*} \\
(2.3785)\end{array}$ & $\begin{array}{r}0.2322 * * * \\
(0.0157)\end{array}$ & $\begin{array}{r}1.7014 \\
(2.3548)\end{array}$ \\
\hline Leverage (Alternative) & $\begin{array}{r}0.0955^{* * *} \\
(0.0091)\end{array}$ & $\begin{array}{r}-2.9784 * * \\
(1.2136)\end{array}$ & $\begin{array}{r}0.0086 \\
(0.0054)\end{array}$ & $\begin{array}{r}5.4886 * * * \\
(1.4340)\end{array}$ & $\begin{array}{r}130.4245 * * * \\
(14.3713)\end{array}$ & $\begin{array}{l}-1.9327 \\
(1.2430)\end{array}$ & $\begin{array}{r}0.0923 * * * \\
(0.0089)\end{array}$ & $\begin{array}{r}-3.4472^{* * * *} \\
(1.2617)\end{array}$ \\
\hline Liquidity (Alternative) & $\begin{array}{r}-0.0017 * * * \\
(0.0005)\end{array}$ & $\begin{array}{l}0.0501 * \\
(0.0299)\end{array}$ & $\begin{array}{r}-0.0005 * * * \\
(0.0002)\end{array}$ & $\begin{array}{r}-0.0175 \\
(0.0431)\end{array}$ & $\begin{array}{r}-2.9668 * * * \\
(0.6956)\end{array}$ & $\begin{array}{r}0.0620 * * \\
(0.0281)\end{array}$ & $\begin{array}{r}-0.0016 * * * * \\
(0.0005)\end{array}$ & $\begin{array}{c}0.0572^{*} \\
(0.0313)\end{array}$ \\
\hline Firm Size & $\begin{array}{r}-0.0000^{* * *} \\
(0.0000)\end{array}$ & $\begin{array}{r}0.0000 * * * * \\
(0.0000)\end{array}$ & $\begin{array}{r}0.0000 * * * \\
(0.0000)\end{array}$ & $\begin{array}{r}-0.0000 * * * * \\
(0.0000)\end{array}$ & $\begin{array}{r}-0.0000 * * * \\
(0.0000)\end{array}$ & $\begin{array}{r}0.0000 * * * \\
(0.0000)\end{array}$ & $\begin{array}{r}-0.0000 * * * \\
(0.0000)\end{array}$ & $\begin{array}{r}0.0000 * * * \\
(0.0000)\end{array}$ \\
\hline Inflation & $\begin{array}{l}-0.0004 \\
(0.0017)\end{array}$ & $\begin{array}{r}0.1162 \\
(0.2175)\end{array}$ & $\begin{array}{r}0.0063^{* * * *} \\
(0.0015)\end{array}$ & $\begin{array}{r}-0.9219 * * \\
(0.3682)\end{array}$ & $\begin{array}{r}-6.5652^{* * *} \\
(2.9605)\end{array}$ & $\begin{array}{r}0.3538 \\
(0.2339)\end{array}$ & $\begin{array}{l}-0.0020 \\
(0.0017)\end{array}$ & $\begin{array}{r}0.2155 \\
(0.2324)\end{array}$ \\
\hline GDP & $\begin{array}{r}-0.0000^{* * *} \\
(0.0000)\end{array}$ & $\begin{array}{r}0.0000 * * * \\
(0.0000)\end{array}$ & $\begin{array}{r}0.0000 * * * \\
(0.0000)\end{array}$ & $\begin{array}{r}-0.0000 * * * \\
(0.0000)\end{array}$ & $\begin{array}{r}-0.0000 * * * \\
(0.0000)\end{array}$ & $\begin{array}{r}0.0000 * * * \\
(0.0000)\end{array}$ & $\begin{array}{r}-0.0000 * * * * \\
(0.0000)\end{array}$ & $\begin{array}{r}0.0000^{* * * *} \\
(0.0000)\end{array}$ \\
\hline PDI & $\begin{array}{r}0.0023 * * * \\
(0.0005)\end{array}$ & $\begin{array}{r}0.2381 * * * \\
(0.0635)\end{array}$ & $\begin{array}{r}0.0137 * * * \\
(0.0005)\end{array}$ & $\begin{array}{r}-2.3237 * * * * \\
(0.1665)\end{array}$ & $\begin{array}{c}-1.6862^{*} \\
(0.9449)\end{array}$ & $\begin{array}{r}0.5470 * * * \\
(0.0676)\end{array}$ & $\begin{array}{r}-0.0019 * * * \\
(0.0005)\end{array}$ & $\begin{array}{r}0.6461 * * * \\
(0.0670)\end{array}$ \\
\hline INDI & $\begin{array}{r}0.0028 * * * \\
(0.0006)\end{array}$ & $\begin{array}{r}0.5752 * * * \\
(0.0699)\end{array}$ & $\begin{array}{r}0.0240 * * * \\
(0.0005)\end{array}$ & $\begin{array}{r}-4.1407 * * * \\
(0.2527)\end{array}$ & $\begin{array}{r}-5.4375^{* * *} \\
(0.9934)\end{array}$ & $\begin{array}{r}1.1647 * * * \\
(0.0755)\end{array}$ & $\begin{array}{r}-0.0043 * * * \\
(0.0006)\end{array}$ & $\begin{array}{r}1.2843 * * * \\
(0.0761)\end{array}$ \\
\hline MAS & $\begin{array}{l}-0.0009 \\
(0.0006)\end{array}$ & $\begin{array}{r}-0.7518^{* * * *} \\
(0.0893)\end{array}$ & $\begin{array}{r}-0.0264 * * * \\
(0.0006)\end{array}$ & $\begin{array}{r}4.6883 * * * * \\
(0.2705)\end{array}$ & $\begin{array}{r}9.2354 * * * \\
(1.1377)\end{array}$ & $\begin{array}{r}-1.3960 * * * \\
(0.0973)\end{array}$ & $\begin{array}{r}0.0068 * * * \\
(0.0007)\end{array}$ & $\begin{array}{r}-1.5382 * * * \\
(0.0977)\end{array}$ \\
\hline UAI & $\begin{array}{r}0.0028 * * * \\
(0.0003)\end{array}$ & $\begin{array}{r}0.2223 * * * \\
(0.0363)\end{array}$ & $\begin{array}{r}0.0042 * * * \\
(0.0002)\end{array}$ & $\begin{array}{r}-0.4072^{* * * *} \\
(0.0670)\end{array}$ & $\begin{array}{r}3.6336 * * * \\
(0.4858)\end{array}$ & $\begin{array}{r}0.2655 * * * \\
(0.0382)\end{array}$ & $\begin{array}{r}0.0015 * * * \\
(0.0003)\end{array}$ & $\begin{array}{r}0.3407 * * * \\
(0.0375)\end{array}$ \\
\hline LTO & $\begin{array}{r}0.0013^{* * * *} \\
(0.0005)\end{array}$ & $\begin{array}{r}0.8027 * * * \\
(0.0608)\end{array}$ & $\begin{array}{r}0.0283^{* * * *} \\
(0.0005)\end{array}$ & $\begin{array}{r}-4.8971 * * * \\
(0.2697)\end{array}$ & $\begin{array}{r}-9.9151 * * * \\
(0.8422)\end{array}$ & $\begin{array}{r}1.5348 * * * \\
(0.0673)\end{array}$ & $\begin{array}{r}-0.0074 * * * \\
(0.0005)\end{array}$ & $\begin{array}{r}1.6878^{* * * *} \\
(0.0682)\end{array}$ \\
\hline IVR & $\begin{array}{r}-0.0028^{* * *} \\
(0.0003)\end{array}$ & $\begin{array}{r}0.3862^{* * * *} \\
(0.0443)\end{array}$ & $\begin{array}{r}0.0147 * * * \\
(0.0004)\end{array}$ & $\begin{array}{r}-2.8837 * * * \\
(0.1482)\end{array}$ & $\begin{array}{r}-10.9165^{* * * *} \\
(0.6222)\end{array}$ & $\begin{array}{r}0.8014 * * * \\
(0.0527)\end{array}$ & $\begin{array}{r}-0.0070 * * * \\
(0.0004)\end{array}$ & $\begin{array}{r}0.8307 * * * \\
(0.0525)\end{array}$ \\
\hline Constant & $\begin{array}{l}-0.0166 \\
(0.1044)\end{array}$ & $\begin{array}{r}-66.4575^{* * *} \\
(9.7381) \\
\end{array}$ & $\begin{array}{r}-3.0132 * * * \\
(0.0975) \\
\end{array}$ & $\begin{array}{r}514.0769 * * * \\
(30.4875) \\
\end{array}$ & $\begin{array}{r}802.2977 * * * \\
(192.8810) \\
\end{array}$ & $\begin{array}{r}-146.0084^{* * *} \\
(10.4739) \\
\end{array}$ & $\begin{array}{r}0.9275 * * * \\
(0.1040) \\
\end{array}$ & $\begin{array}{r}-159.8460 * * * \\
(11.0148) \\
\end{array}$ \\
\hline Observations & 14213 & 12556 & 14213 & 12556 & 14213 & 12556 & 14213 & 12556 \\
\hline R-squared & 0.3433 & & 0.7552 & & 0.4499 & & 0.3484 & \\
\hline $\begin{array}{l}\text { Shea's Partial R-squared } \\
\text { Weak identification test }\end{array}$ & 0.1419 & & 0.0845 & & 0.1256 & & 0.1261 & \\
\hline $\begin{array}{l}\text { K-P rk Wald F-statistic } \\
\text { Overidentification Test }\end{array}$ & 1502.714 & & 647.867 & & 1279.643 & & 1336.450 & \\
\hline Hansen J-statistics (p-value) & 1.000 & & 0.2368 & & 1.000 & & 1.000 & \\
\hline Industry FE & Yes & Yes & Yes & Yes & Yes & Yes & Yes & Yes \\
\hline Year FE & Yes & Yes & Yes & Yes & Yes & Yes & Yes & Yes \\
\hline
\end{tabular}

Notes: Table 7- Panel C provides the results of the regressions of director's networks on Environment score with other firm characteristics using 2SLS estimation techniques. The instruments used in this equation are: $I V$-UGrad and IV-Board Size. The dependent variable is Environment Score. Degree (Number of all direct links of each director with other directors), closeness (inverse of the sum of shortest distance between the 
focal director and all other directors), betweenness (probability that a director lies on the shortest path between any other two directors), eigenvector (the influence of a director in a network), ROE (ratio of net income to book value on equity), firm size (industry adjusted natural logarithm of total assets), Leverage (Alternative) (book value of long-term debt plus debt in current liabilities minus short and long-term investments divided by total assets). Liquidity (Alternative) (ratio of current assets to current liabilities), duality (equals to 1 when a CEO or member of the executive board also the chairman of the board, and 0 otherwise), G-index (a governance index to capture firm-level investor protection). National culture is represented by PDI (Power distance), INDI (Individualism), MAS (Masculinity), UAI (Uncertainty avoidance), LTO (Long-term orientation), IVR (Indulgence versus Restraint). K-P (Kleibergen-Paap) rk Wald F-statistic for weak instrument test and Hansen J-statistics for overidentification test are reported. All reported t-values in parentheses are based on robust standard errors adjusted for clustering by firm. *, **, *** refer to significance at the $10 \%, 5 \%$, and $1 \%$ levels, respectively. 
Table 7 Panel D: Impact of Centrality on CSR using 2SLS -with alternative measures of leverage and liquidity

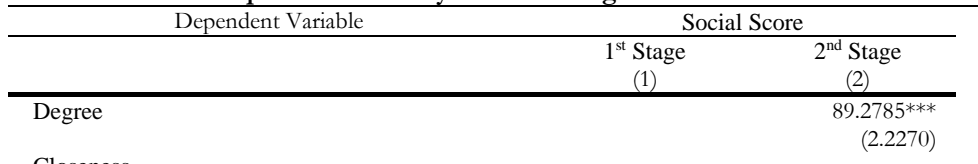

Closeness

Betweenness

Eigenvector

IV-UGrad
IV-Board Size

ROE

G-index

Leverage (Alternative)

Liquidity (Alternative)

Firm Size

Inflation

GDP

PDI

INDI

MAS

UAI

LTO

IVR

Constant

Observatio

R-squared

Shea's Partial R-square

Weak identification test

Overidentification Test

Hansen J-statistics (p-value)

Industry FE
Year FE

$\begin{array}{rr}0.0213^{* *} & \\ (0.0084) & \\ 0.0381 * * & \\ (0.0009) & \\ 0.0000 * * * & -0.0005 \\ (0.0000) & (0.0012) \\ 0.2335 * * & 7.8723 * * * \\ (0.0160) & (2.0853) \\ 0.0955 * * * & -2.7192 * * \\ (0.0091) & (1.0875) \\ -0.0017 * * * & -0.0102 \\ (0.0005) & (0.0206) \\ -0.0000 * * * & 0.0000 * * * \\ (0.0000) & (0.0000) \\ -0.0004 & 0.4127 * \\ (0.0017) & (0.2162) \\ -0.0000 * * * & 0.0000 * * * \\ (0.0000) & (0.0000) \\ 0.0023 * * * & 0.4189 * * * \\ (0.0005) & (0.0606) \\ 0.0028 * * & 0.6875 * * * \\ (0.0006) & (0.0688) \\ -0.0009 & -1.0485 * * * \\ (0.0006) & (0.0918) \\ 0.0002 * * * & 0.2690 * * * \\ (0.0003) & (0.0372) \\ 0.0013 * * & 0.8790 * * * \\ (0.0005) & (0.0596) \\ -0.0028 * * * & 0.5305 * * * \\ (0.0003) & (0.0434) \\ -0.0166 & -73.2577 * * * \\ (0.1044) & (8.6098) \\ 14213 & 12556 \\ 0.3433 & \\ 0.1419 & \end{array}$

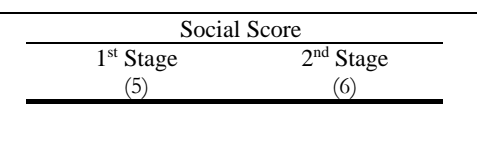

$96.0043 * * *$

(7.4922)

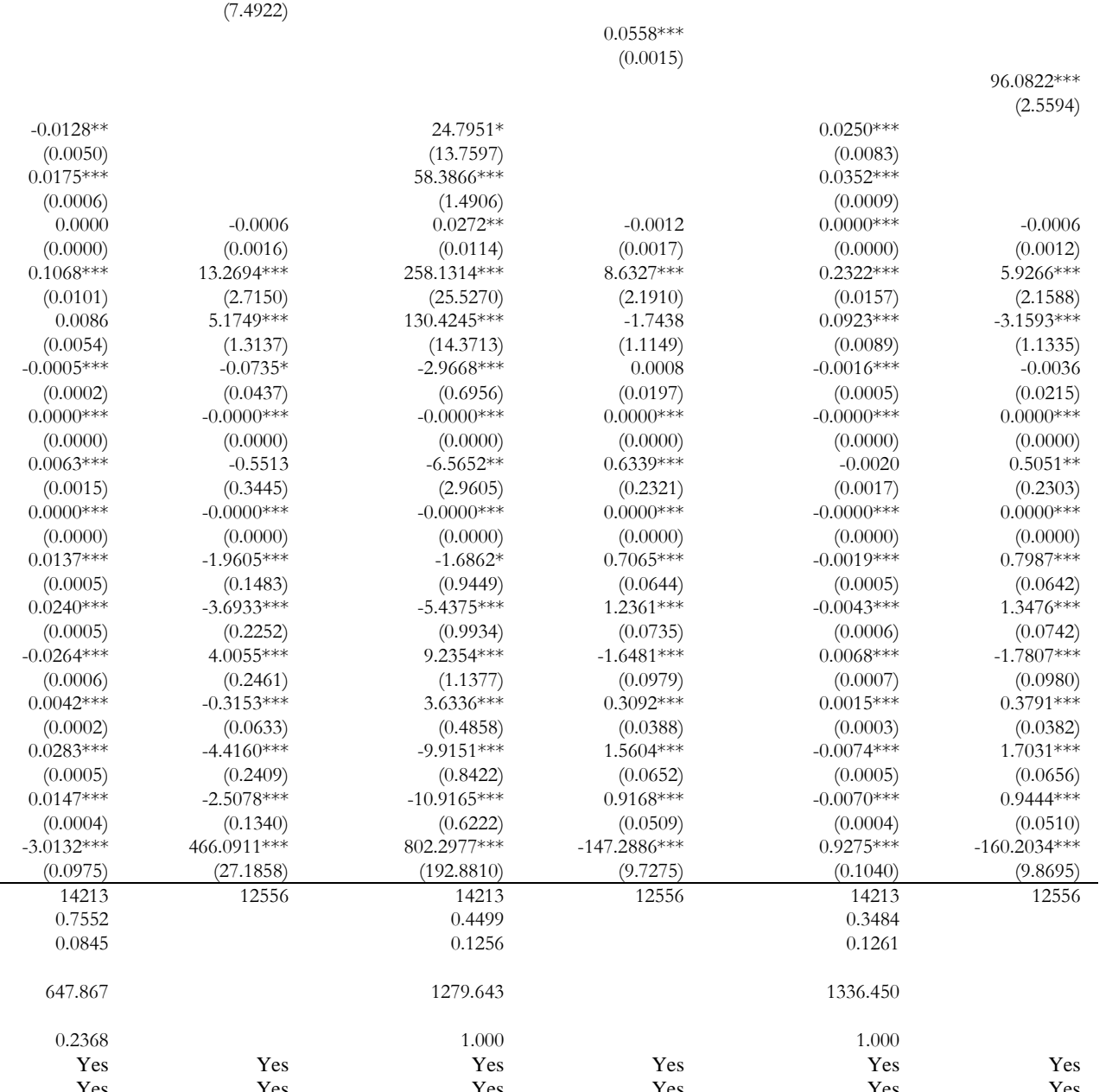

Notes: Table 7- Panel D provides the results of the regressions of director's networks on Social score with other firm characteristics using 2SLS estimation techniques. The instruments

used in this equation are: IV-UGrad and IV-Board Size. The dependent variable is Social Score. Degree (Number of all direct links of each director with other directors), closeness 
(inverse of the sum of shortest distance between the focal director and all other directors), betweenness (probability that a director lies on the shortest path between any other two directors), eigenvector (the influence of a director in a network), ROE (ratio of net income to book value on equity), firm size (industry adjusted natural logarithm of total assets), Leverage (Alternative) (book value of long-term debt plus debt in current liabilities minus short and long-term investments divided by total assets). Liquidity (Alternative) (ratio of current assets to current liabilities), duality (equals to 1 when a CEO or member of the executive board also the chairman of the board, and 0 otherwise), G-index (a governance index to capture firm-level investor protection). National culture is represented by PDI (Power distance), INDI (Individualism), MAS (Masculinity), UAI (Uncertainty avoidance), LTO (Longterm orientation), IVR (Indulgence versus Restraint). K-P (Kleibergen-Paap) rk Wald F-statistic for weak instrument test and Hansen J-statistics for overidentification test are reported. All reported $\mathrm{t}$-values in parentheses are based on robust standard errors adjusted for clustering by firm. *, **, *** refer to significance at the $10 \%, 5 \%$, and $1 \%$ levels, respectively. 
Table 8- Panel A: Impact of director's networks on CSR using random effects

\begin{tabular}{|c|c|c|c|c|c|c|c|c|}
\hline 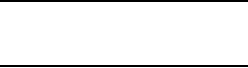 & $\begin{array}{l}(1) \\
\text { ES } \\
\end{array}$ & $\begin{array}{l}(2) \\
\text { ES }\end{array}$ & $\begin{array}{l}(3) \\
\text { ES }\end{array}$ & $\begin{array}{l}(4) \\
\text { ES }\end{array}$ & $\begin{array}{l}\text { (5) } \\
\text { SS } \\
\end{array}$ & $\begin{array}{l}6) \\
\text { SS }\end{array}$ & $\begin{array}{l}7) \\
\text { SS }\end{array}$ & $\begin{array}{l}(8) \\
\text { SS }\end{array}$ \\
\hline Degree & $\begin{array}{r}42.6041^{* * * *} \\
(1.9524)\end{array}$ & & & & $\begin{array}{r}44.3088 * * * \\
(1.7940)\end{array}$ & & & \\
\hline Closeness & & $\begin{array}{r}26.9623 * * * \\
(2.8312)\end{array}$ & & & & $\begin{array}{r}36.5035 * * * \\
(2.6416)\end{array}$ & & \\
\hline Betweenness & & & $\begin{array}{r}0.0129 * * * \\
(0.0009)\end{array}$ & & & & $\begin{array}{r}0.0085^{* * * *} \\
(0.0008)\end{array}$ & \\
\hline Eigenvector & & & & $42.8906 * * *$ & & & & $44.1053 * * *$ \\
\hline All control variables & Included & Included & Included & Included & Included & Included & Included & Included \\
\hline Constant & $\begin{array}{r}31.2311 * * * \\
(1.8140)\end{array}$ & $\begin{array}{r}47.7436^{* * *} \\
(1.9019)\end{array}$ & $\begin{array}{r}31.9959 * * * \\
(1.8477)\end{array}$ & $\begin{array}{r}29.3920 * * * \\
(1.8209)\end{array}$ & $\begin{array}{r}46.2964 * * * \\
(1.6172)\end{array}$ & $\begin{array}{r}62.7300^{* * *} \\
(1.7235)\end{array}$ & $\begin{array}{r}47.6327 * * * \\
(1.6629)\end{array}$ & $\begin{array}{r}44.3988^{* * *} \\
(1.6229)\end{array}$ \\
\hline Observations & 14965 & 14965 & 14965 & 14965 & 14965 & 14965 & 14965 & 14965 \\
\hline R-squared & 0.29 & 0.19 & 0.27 & 0.29 & 0.33 & 0.21 & 0.29 & 0.33 \\
\hline Industry FE & Yes & Yes & Yes & Yes & Yes & Yes & Yes & Yes \\
\hline Year FE & Yes & Yes & Yes & Yes & Yes & Yes & Yes & Yes \\
\hline Country FE & Yes & Yes & Yes & Yes & Yes & Yes & Yes & Yes \\
\hline
\end{tabular}

Notes: Table 8 Panel A provides the results of the regressions of director's networks on ES and SS using random effect estimation.

Panel B: Impact of director's networks on CSR using Heckman selection model

\begin{tabular}{|c|c|c|c|c|c|c|c|c|}
\hline & (1) & (2) & (3) & (4) & (5) & (6) & (7) & (8) \\
\hline & ES & ES & ES & ES & SS & SS & SS & SS \\
\hline Degree & $\begin{array}{r}47.4080 * * * \\
(0.8348)\end{array}$ & & & & $\begin{array}{r}46.6845 * * * \\
(0.7520)\end{array}$ & & & \\
\hline Closeness & & $\begin{array}{r}12.9336 * * * \\
(0.9024)\end{array}$ & & & & $\begin{array}{r}17.1871 * * * \\
(0.8201)\end{array}$ & & \\
\hline Betweenness & & & $\begin{array}{r}0.0260^{* * *} \\
(0.0005)\end{array}$ & & & & $\begin{array}{r}0.0239 * * * \\
(0.0004)\end{array}$ & \\
\hline Eigenvector & & & & $\begin{array}{r}43.9263 * * * \\
(0.8442)\end{array}$ & & & & $\begin{array}{r}43.1295 * * * \\
(0.7631)\end{array}$ \\
\hline $\begin{array}{l}\text { All control variables } \\
\text { Constant }\end{array}$ & $\begin{array}{r}\text { Included } \\
3.3576 * * * \\
(0.0058) \\
\end{array}$ & $\begin{array}{r}\text { Included } \\
3.4476^{* * *} * \\
(0.0058) \\
\end{array}$ & $\begin{array}{r}\text { Included } \\
3.3572 * * * \\
(0.0058) \\
\end{array}$ & $\begin{array}{r}\text { Included } \\
3.3720 * * * \\
(0.0058) \\
\end{array}$ & $\begin{array}{r}\text { Included } \\
3.2529 * * * \\
(0.0058) \\
\end{array}$ & $\begin{array}{r}\text { Included } \\
3.3521 * * * \\
(0.0058)\end{array}$ & $\begin{array}{r}\text { Included } \\
3.2686^{* * *} * \\
(0.0058) \\
\end{array}$ & $\begin{array}{r}\text { Included } \\
3.2707 * * * \\
(0.0058) \\
\end{array}$ \\
\hline $\begin{array}{l}\text { Observations } \\
\text { Industry FE }\end{array}$ & $\begin{array}{r}16919 \\
\text { Yes } \\
\end{array}$ & $\begin{array}{r}16919 \\
\text { Yes } \\
\end{array}$ & $\begin{array}{r}16919 \\
\text { Yes } \\
\end{array}$ & $\begin{array}{r}16919 \\
\text { Yes } \\
\end{array}$ & $\begin{array}{r}16919 \\
\text { Yes } \\
\end{array}$ & $\begin{array}{r}16919 \\
\text { Yes } \\
\end{array}$ & $\begin{array}{r}16919 \\
\text { Yes } \\
\end{array}$ & $\begin{array}{r}16919 \\
\text { Yes }\end{array}$ \\
\hline
\end{tabular}

Notes: Table 8 Panel B reports the results of the regressions of director's networks on ES and SS using Heckman selection model.

Table 8A \& 8B: The dependent variable is Environment Score (ES) Social Score (SS). Degree (Number of all direct links of each director with other directors), closeness (inverse of the sum of shortest distance between the focal director and all other directors), betweenness (probability that a director lies on the shortest path between any other two directors), eigenvector (the influence of a director in a network). All control variables (as in Table 3A \& B) are included but not reported. All reported t-values in parentheses are based on robust standard errors adjusted for clustering by firm. *,**,*** refer to significance at the $10 \%, 5 \%$, and $1 \%$ levels, respectively. 
Table 9: The effects of corporate governance

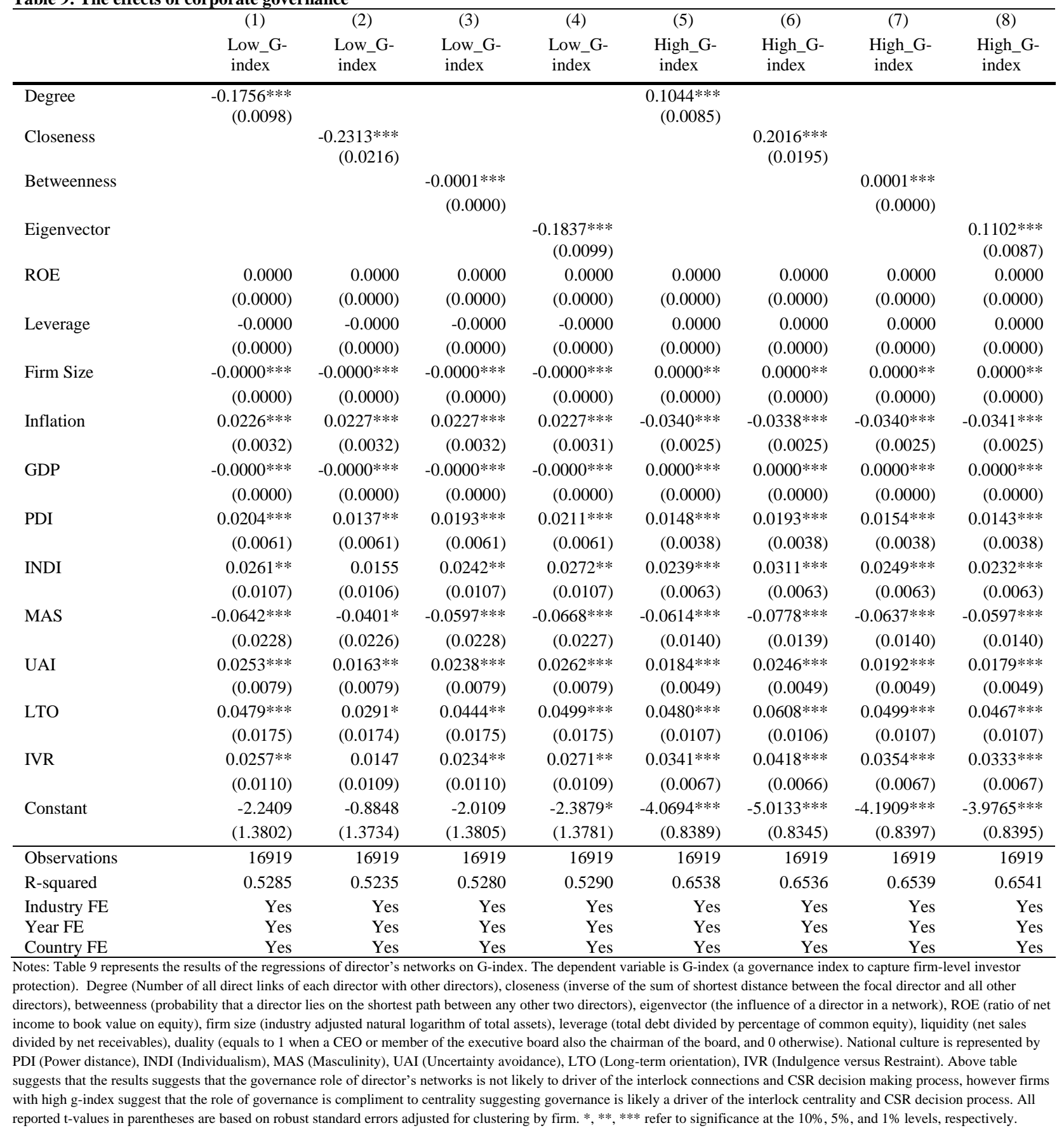


Table 10: Impact of Personal and Professional networks on CSR

\begin{tabular}{|c|c|c|c|c|}
\hline & (1) & (2) & (3) & (4) \\
\hline & ES & ES & SS & SS \\
\hline Personal Network & $\begin{array}{r}0.0492 * * * \\
(0.0132)\end{array}$ & & & $\begin{array}{r}0.0575 * * * \\
(0.0123)\end{array}$ \\
\hline Professional Network & & $\begin{array}{r}0.2080^{* * * *} \\
(0.0167)\end{array}$ & $\begin{array}{r}0.2099 * * * \\
(0.0149)\end{array}$ & \\
\hline ROE & $\begin{array}{r}0.0011 \\
(0.0017)\end{array}$ & $\begin{array}{r}0.0010 \\
(0.0017)\end{array}$ & $\begin{array}{r}0.0016 \\
(0.0019)\end{array}$ & $\begin{array}{r}0.0016 \\
(0.0019)\end{array}$ \\
\hline G-index & $\begin{array}{r}15.1487 * * * \\
(2.1808)\end{array}$ & $\begin{array}{r}15.3157 * * * \\
(2.1583)\end{array}$ & $\begin{array}{r}20.0922 * * * * \\
(2.0035)\end{array}$ & $\begin{array}{r}19.9207 * * * \\
(2.0277)\end{array}$ \\
\hline Leverage & $\begin{array}{r}-0.0001 \\
(0.0001)\end{array}$ & $\begin{array}{r}-0.0001 \\
(0.0001)\end{array}$ & $\begin{array}{r}-0.0001 * * \\
(0.0001)\end{array}$ & $\begin{array}{r}-0.0001 * \\
(0.0001)\end{array}$ \\
\hline Firm Size & $\begin{array}{r}0.0000 * * * \\
(0.0000)\end{array}$ & $\begin{array}{r}0.0000 * * * * \\
(0.0000)\end{array}$ & $\begin{array}{r}0.0000^{* * * *} \\
(0.0000)\end{array}$ & $\begin{array}{r}0.0000^{* * * *} \\
(0.0000)\end{array}$ \\
\hline Inflation & $\begin{array}{r}-0.3054 \\
(0.2419)\end{array}$ & $\begin{array}{r}-0.2634 \\
(0.2400)\end{array}$ & $\begin{array}{r}-0.2724 \\
(0.2321)\end{array}$ & $\begin{array}{r}-0.3162 \\
(0.2345)\end{array}$ \\
\hline GDP & $\begin{array}{r}0.0000 * * * * \\
(0.0000)\end{array}$ & $\begin{array}{r}0.0000^{* * * *} \\
(0.0000)\end{array}$ & $\begin{array}{r}0.0000^{* * * *} \\
(0.0000)\end{array}$ & $\begin{array}{r}0.0000 * * * \\
(0.0000)\end{array}$ \\
\hline PDI & $\begin{array}{r}1.7624 * * * * \\
(0.4474)\end{array}$ & $\begin{array}{r}2.1241 * * * \\
(0.4447)\end{array}$ & $\begin{array}{r}0.8509 * * \\
(0.4023)\end{array}$ & $\begin{array}{r}0.4892 \\
(0.4034)\end{array}$ \\
\hline INDI & $\begin{array}{r}2.8427 * * * \\
(0.7503)\end{array}$ & $\begin{array}{r}3.4378^{* * *} * \\
(0.7457)\end{array}$ & $\begin{array}{c}1.2629^{*} \\
(0.6633)\end{array}$ & $\begin{array}{r}0.6671 \\
(0.6641)\end{array}$ \\
\hline MAS & $\begin{array}{r}-6.8422 * * * \\
(1.6058)\end{array}$ & $\begin{array}{r}-8.2808 * * * \\
(1.5959)\end{array}$ & $\begin{array}{r}-3.5964 * * \\
(1.4095)\end{array}$ & $\begin{array}{l}-2.1515 \\
(1.4116)\end{array}$ \\
\hline UAI & $\begin{array}{r}2.7388^{* * * *} \\
(0.5618)\end{array}$ & $\begin{array}{r}3.2240^{* * *} \\
(0.5582)\end{array}$ & $\begin{array}{r}1.5008^{* * * *} \\
(0.4939)\end{array}$ & $\begin{array}{r}1.0133^{* *} \\
(0.4948)\end{array}$ \\
\hline LTO & $\begin{array}{r}5.2497 * * * \\
(1.2325)\end{array}$ & $\begin{array}{r}6.3605 * * * * \\
(1.2248)\end{array}$ & $\begin{array}{r}2.5721 * * \\
(1.0794)\end{array}$ & $\begin{array}{r}1.4592 \\
(1.0812)\end{array}$ \\
\hline IVR & $\begin{array}{r}2.8310^{* * *} \\
(0.7668)\end{array}$ & $\begin{array}{r}3.5626 * * * \\
(0.7620)\end{array}$ & $\begin{array}{r}1.3150^{* *} \\
(0.6607)\end{array}$ & $\begin{array}{r}0.5841 \\
(0.6618)\end{array}$ \\
\hline Constant & $\begin{array}{r}-341.0788 * * * \\
(97.7442) \\
\end{array}$ & $\begin{array}{r}-429.5489^{* * * *} \\
(97.1378) \\
\end{array}$ & $\begin{array}{r}-127.7894 \\
(85.7208)\end{array}$ & $\begin{array}{r}-39.5541 \\
(85.8998)\end{array}$ \\
\hline Observations & 14965 & 14965 & 14965 & 14965 \\
\hline R-squared & 0.1588 & 0.1782 & 0.1820 & 0.1587 \\
\hline Industry FE & Yes & Yes & Yes & Yes \\
\hline Year FE & Yes & Yes & Yes & Yes \\
\hline Country FE & Yes & Yes & Yes & Yes \\
\hline
\end{tabular}

Notes: Table 10 shows the regressions of director's networks on personal (number of directors with whom the focal director attended the same institutions, graduated within two years and awarded similar type of degrees) and professional networks (number of directors with whom the focal director shares a common board). The dependent variable is Environment Social (ES) and Social Score (SS). Degree (Number of all direct links of each director with other directors), closeness (inverse of the sum of shortest distance between the focal director and all other directors), betweenness (probability that a director lies on the shortest path between any other two directors), eigenvector (the influence of a director in a network), ROE (ratio of net income to book value on equity), firm size (industry adjusted natural logarithm of total assets), leverage (total debt divided by percentage of common equity), liquidity (net sales divided by net receivables), duality (equals to 1 when a CEO or member of the executive board also the chairman of the board, and 0 otherwise), G-index (a governance index to capture firm-level investor protection). National culture is represented by PDI (Power distance), INDI (Individualism), MAS (Masculinity), UAI (Uncertainty avoidance), LTO (Long-term orientation), IVR (Indulgence versus Restraint).All reported t-values in parentheses are based on robust standard errors adjusted for clustering by firm. *, **, *** refer to significance at the $10 \%, 5 \%$, and $1 \%$ levels, respectively. 


\section{Appendix A}

Data Source

\begin{tabular}{ll}
\hline Variable & Definition and calculation \\
\hline $\begin{array}{l}\text { CSR variables } \\
\text { Environmental Score } \\
\text { (ES) }\end{array}$ & $\begin{array}{l}\text { ES is a measure of firm's impact on living and non-living natural systems. } \\
\text { The score is obtained from the database. } \\
\text { SS is measure of firm's capacity to generate trust and loyalty with its } \\
\text { important stakeholders. The score is obtained from the database }\end{array}$ \\
Centrality & $\begin{array}{l}\text { Number of all direct links that each director has with other directors in the } \\
\text { network. } \\
\text { The inverse of the sum of shortest distance between the focal director and all } \\
\text { other directors in a network. } \\
\text { The probability that a director lies on the shortest path between any other two } \\
\text { directors of the network. }\end{array}$ \\
Betweenness & $\begin{array}{l}\text { Measures the influence of a director in a network. } \\
\text { Eigenvector }\end{array}$ \\
Director's network & $\begin{array}{l}\text { Total number of directors with whom the focal director shares a common } \\
\text { board. }\end{array}$ \\
Professional Network & $\begin{array}{l}\text { Total number of directors with whom the focal director attended the same } \\
\text { Personal Network }\end{array}$
\end{tabular}

\section{Control variables}

ROE

Firm Size

Leverage institutions, graduated within two years and awarded similar type of degrees.

ASSET4

ASSET4

BoardEx and authors' calculation

BoardEx and authors' calculation

BoardEx and authors' calculation

BoardEx and authors' calculation

BoardEx and authors' calculation

BoardEx and authors' calculation

Worldscope

Worldscope

Worldscope

Worldscope

Worldscope

Worldscope

BoardEx also the chairman of the board, and 0 otherwise.

The G-index is governance index and captures firm-level investor protection, with higher (lower) G-indexes indicating worse (better) investor protection. See Gompers, Ishii and Metrick index (2003) for more details.

\section{Real GDP}

GDP

Inflation

Consumer Price Index

Power distance: based on the degree of equality of individuals in a country.

More centralized authority with levels of hierarchy and supervision characterizes higher power distance countries. Lower power distance countries have more decentralized authority and with more participatory management.

INDI

Individualism: people in a society consider their own interests without taking the interests of the society as a whole into account. In a low individualism (i.e. high collectivism) country, employees of a firm are considered members of the family of the firm and their interests are more closely aligned with the firm. This can lead to the development of powerful networks that are more susceptible to corruption.

Masculinity: represents a preference for achievement, assertiveness, control, and power. In high masculine countries, managers strive for achievement and recognition.

Uncertainty avoidance: represents a society's tolerance for uncertainty and ambiguity. High uncertainty avoidance countries tend to have stricter rules and laws and individuals value precision and punctuality. Individuals in low uncertainty avoidance countries tend to be more flexible and have higher tolerances for differing opinions.
Hofstede (1984)

\section{ASSET4}

Worldscope

Worldscope

Hofstede (1984)

Hofstede (1984)

Hofstede (1984)

Hofstede (1984)
Long-term orientation: individuals in a long-term-oriented country are focused on long-term goals. High scores are likely to indicate that thrift and persistence are rewarded and that social behavior is oriented towards future 
rewards. Values in a society with short-term orientation are related to the traits of spending extravagantly and to using available resources instantaneously for quick results.

Indulgence versus Restraint: This dimension represents a trade off between indulgence and restraint. In an indulgent culture, individuals are more

IVR optimistic and feel that they have more control over their lives and are more impulsive. Friends are important and freedom of speech is common. In a restrained culture, individuals feel that life is hard and duty rather than freedom is more normal. Stricter moral discipline.

Hofstede (1984)

\title{
Instrumental variables
}

UGrad

Binary variable- 1 if directors earned a graduate degree in any field from any

BoardEx institution, 0 otherwise

Board size Total number of directors on a board

\author{
BoardEx
}

Notes: Following are the definitions of the environmental and social pillars by Thomson Reuters (2019). "The environmental pillar measures afirm's impact on living and non-living natural systems, including the air, land and water, as well as complete ecosystems. It reflects how well a firm uses best management practices to avoid environmental risks and capitalizes on environmental opportunities in order to generate long term shareholder value". "The social pillar measures a firm's capacity to generate trust and loyalty with its workforce, customers and society, through its use of best management practices. It is a reflection of the firm's reputation and the health of its license to operate, which are key factors in determining its ability to generate long term shareholder value." 


\section{Appendix B: Calculation of centrality measures}

The networks connections used in this study includes four centrality measures introduced by network theory by Freeman (1977) and Proctor and loomis (1951): Degree centrality, Closeness centrality, Betweenness centrality and Eigenvector centrality. These measures capture not only connections but the quality of those connections. Each centrality measure captures distinct aspects of the relative importance of every connection in the entire network (Intintoli et al., 2018).

\begin{tabular}{|c|c|c|}
\hline Centrality & Formula & Source \\
\hline Degree & $\begin{array}{l}\qquad D_{i}=\Sigma_{j \neq} x_{i j} \\
\text { where xij is } 1 \text { for the presence of a social connection between i and } \mathrm{j} \text {. } \\
\text { This centrality measure captures the number of direct ties an individual has } \\
\text { with other individuals in the networks. The higher the connections, the } \\
\text { more important individual is in the network. }\end{array}$ & $\begin{array}{l}\text { El-Khatib et al., } \\
\text { (2015); Intintoli } \\
\text { et al, (2018) }\end{array}$ \\
\hline Closeness & $\begin{array}{l}\qquad C_{i}=\frac{n-1}{\sum_{i \neq j \in N} d_{i j}} X \frac{n}{N} \\
\text { Where dij is the shortest distance between nodes i and } \mathrm{j}, \mathrm{n} \text { is the size of the component i belongs to, and } \mathrm{N} \text { is the } \\
\text { size of the yearly network. } \\
\text { This centrality measure captures how quick an individual can access other } \\
\text { individuals in the network. The closer the individual is, the higher their } \\
\text { chances to obtain access to invaluable information, resulting in greater } \\
\text { influence on other individuals and higher social power. }\end{array}$ & $\begin{array}{l}\text { El-Khatib et al., } \\
\text { (2015); Intintoli } \\
\text { et al., (2018) }\end{array}$ \\
\hline Betweenness & $\begin{array}{l}B_{k}=\Sigma_{i<j \neq \epsilon N} \frac{g_{i j} / g_{i j}}{(n-1)(n 2) / 2} \\
\text { Where gij is } 1 \text { for any geodesic connecting } \mathrm{i} \text { and } \mathrm{j} \text {, and gij(k) is assigned a value of } 1 \text { if the geodesic between i and } \mathrm{j} \\
\text { also passes through k } \\
\text { This centrality measure represents the importance of an individual having } \\
\text { shortest information bridge for other individuals (Freeman 1977). } \\
\text { Betweenness centrality is sum of the shortest paths between all individuals } \\
\text { that pass through a person (Intintoli et al, 2018). Individuals with higher } \\
\text { betweenness centrality can obtain more affluent information. }\end{array}$ & $\begin{array}{l}\text { El-Khatib et al., } \\
\text { (2015); Intintoli } \\
\text { et al., (2018) }\end{array}$ \\
\hline Eigenvector & $\begin{array}{l}\mathrm{E}_{\mathrm{i}} \text { is solved by satisfying } \lambda \mathrm{E}^{\prime} \mathrm{E}=\mathrm{E}^{\prime} \mathrm{AE} \text {, where } \mathrm{E} \text { is an eigenvector of the } \\
\text { matrix of connections } \mathrm{A} \text {, and } \lambda \text { is its associated eigenvalue. } E_{\mathrm{i}} \text { is taken as } \\
\text { the elements of the eigenvector } \mathrm{E}^{*} \text { associated with } \mathrm{A}^{\prime} \text { s principal } \\
\text { eigenvalue, } \lambda^{*} \text {. } \\
\text { Eigenvector centrality is weighted degree centrality measure which } \\
\text { represent how well each direct tie is. This centrality is based on the } \\
\text { concept that not all the individuals connected to provided individual are } \\
\text { equally important. }\end{array}$ & $\begin{array}{l}\text { El-Khatib et al., } \\
\text { (2015); Intintoli } \\
\text { et al., (2018) }\end{array}$ \\
\hline
\end{tabular}




\section{Appendix C: The VIF values}

\begin{tabular}{|c|c|c|c|c|c|c|c|c|}
\hline \multirow[b]{2}{*}{ Variables } & \multicolumn{4}{|c|}{ Dependent $=\mathrm{ES}$} & \multicolumn{4}{|c|}{ Dependent $=$ SS } \\
\hline & Column 1 & Column 2 & Column 3 & Column 4 & Column 5 & Column 6 & Column 7 & Column 8 \\
\hline Degree & 1.17 & & & & 1.17 & & & \\
\hline Closeness & & 5.16 & & & & 5.16 & & \\
\hline Betweenness & & & 1.35 & & & & 1.35 & \\
\hline Eigenvector & & & & 1.21 & & & & 1.21 \\
\hline ROE & 1.00 & 1.00 & 1.00 & 1.00 & 1.00 & 1.00 & 1.00 & 1.00 \\
\hline G-index & 3.71 & 3.70 & 3.71 & 3.71 & 3.71 & 3.71 & 3.71 & 3.71 \\
\hline Leverage & 1.00 & 1.00 & 1.00 & 1.00 & 1.00 & 1.00 & 1.00 & 1.00 \\
\hline Firm Size & 1.65 & 1.65 & 1.65 & 1.65 & 1.65 & 1.65 & 1.65 & 1.65 \\
\hline PDI & 3.33 & 3.33 & 3.33 & 3.33 & 3.33 & 3.33 & 3.33 & 3.33 \\
\hline INDI & 8.62 & 8.62 & 8.62 & 8.62 & 8.62 & 8.62 & 8.62 & 8.62 \\
\hline MAS & 4.06 & 4.06 & 4.06 & 4.06 & 4.06 & 4.06 & 4.06 & 4.06 \\
\hline UAI & 1.83 & 1.83 & 1.83 & 1.83 & 1.83 & 1.83 & 1.83 & 1.83 \\
\hline LTO & 5.21 & 5.21 & 5.21 & 5.21 & 5.21 & 5.21 & 5.21 & 5.21 \\
\hline IVR & 4.07 & 4.07 & 4.07 & 4.07 & 4.07 & 4.07 & 4.07 & 4.07 \\
\hline
\end{tabular}

Notes: Appendix C provides the variance inflation factor (VIF) values. The dependent variable is Environment Score (ES) Social Score (SS). Degree (Number of all direct links of each director with other directors), closeness (inverse of the sum of shortest distance between the focal director and all other directors), betweenness (probability that a director lies on the shortest path between any other two directors), eigenvector (the influence of a director in a network), ROE (ratio of net income to book value on equity), G-index (a governance index to capture firm-level investor protection), leverage (total debt divided by percentage of common equity), liquidity (net sales divided by net receivables), firm size (industry adjusted natural logarithm of total assets). ). National culture is represented by PDI (power distance), INDI (individualism), MAS (Masculinity), UAI (Uncertainty avoidance), LTO (Long-term orientation), IVR (Indulgence versus Restraint). 